\title{
Atholl John Anderson: No ordinary archaeologist
}

\author{
Foss Leach \\ Honorary Research Associate, Museum of New Zealand Te Papa Tongarewa, Wellington, New Zealand \\ Foss.Leach@University-of-Ngakuta.ac.nz
}

Atholl Anderson first ventured into serious archaeological research in 1966, when he carried out an extensive survey of archaeological sites in the Tasman Bay area at the northern end of the South Island of New Zealand. The main objective was 'a complete coverage of all the sites of prehistoric settlement, including mapping, stratigraphical analysis, and sampling of contents'. The completed study was submitted to the Geography Department at Canterbury University as a thesis for the MA degree in 1966 (Maori occupation sites in back beach deposits around Tasman Bay). This was a bold initiative for a budding archaeologist, aged 23, working alone, with no formal training in archaeology - that came later. The degree was awarded with Honours. Like many other young students of the time, he had a Teachers Training College studentship. This was a scheme which provided financial assistance for those bent on a teaching career to attend university. After being awarded the MA degree, he was obliged to attend Training College for a year to complete the requirements for a Diploma in Teaching and thereafter to be placed in a school somewhere in New Zealand. So in 1968, Atholl became the assistant headmaster at the small rural school of Karamea, from time to time doubling as the publican of the local hotel. Karamea, at the northernmost end of the West Coast of the South Island, is famous for its forest and fishing, and provided ample opportunities for his great love of the outdoors. He was married by this time to Sandy, with a daughter Rachel.

In spite of the wonderful attractions of West Coast life, Atholl's burning ambition in life was professional archaeology, and a career in teaching was not leading in the right direction. I first met Atholl late in 1969, when he walked into the Anthropology Department at Otago University to seek advice on how to obtain the necessary qualifications to join mainstream professional archaeology. I was a junior lecturer at the time. He was accepted into the MA course in Anthropology in 1970 and became part of a group of young students the like of which had never been seen before at Otago, and arguably has not been seen since. There was a strong spirit of friendship, collaboration and healthy competition between them, and several have excelled 
academically, with international reputations. Atholl joined a small team of research students in the Palliser Bay archaeological project 1969-1972 and carried out groundbreaking research combining the analysis of a rocky-shore marine environment with high-quality excavation of nearby midden sites and detailed laboratory analysis (1979e, 1981c). This set a standard of maritime economic archaeology which has not been matched in New Zealand since. During this research, he first ventured into archaeometry, greatly improving a novel method of conchiolin dating, which clarified the chronology of the midden sites he excavated (1973b). At this time, he also took his first steps in what was to become one of his strongest academic attributes, archaeological theory, publishing an insightful reappraisal of sampling theory relating to midden excavations. He strongly rejected concepts of cluster, random and column sampling as having fundamental misconceptions. He commented 'leaving the choice of excavation areas to chance is clearly likely to produce results of the same status as those obtained by mixing chemicals at random: A puzzling if not dangerous mess' (1973a:123). He argued that a 'more sensible approach is to ... excavate on the basis of research objectives rather than chance, and to restrict interpretations, in the main, to the results of a full and careful analysis of everything excavated' (1973a:124). Throughout his career, Atholl has been exemplary in this regard. He was awarded his second MA degree in 1973 with First Class Honours (Archaeology and behaviour: Prehistoric subsistence behaviour at Black Rocks peninsula, Palliser Bay).

Following the end of the Palliser Bay project, Atholl applied for a Commonwealth scholarship at Cambridge University with a proposal for doctoral research based in the Chatham Islands, and began fieldwork there early in 1973. During the site survey, a letter from Cambridge University was delivered on horseback during torrential rain while he was digging an underground sauna at the field camp. This contained welcome news of acceptance at Cambridge. After returning to mainland New Zealand, he travelled to England and took up residence in Cambridge with his family. Carrying out further research in the Chatham Islands, on the other side of the world, without research grants was impossible, so he decided to focus on archaeological problems closer at hand. He initially carried out fieldwork in France, before turning attention to northern Sweden. He became sufficiently competent in Swedish to do detailed library research, as well

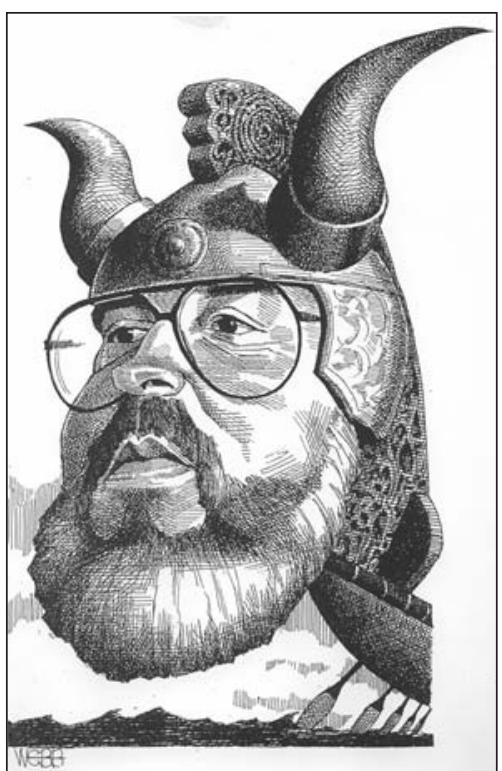

Figure 1. A whimsical portrayal of Atholl as the bow-piece of a canoe (courtesy of Murray Webb, 1987). as intensive fieldwork. This was not without the usual calamities which accompany archaeological fieldwork. On one occasion, out in the mountains in South Lapland on a very hot day, he took a short cut through a large swamp. When he was half way across, the thick layer of sphagnum moss gave way and he very nearly disappeared in deep liquid mud underneath. In one of the wonderful newsy letters which he frequently wrote from abroad, he described this close encounter thus:

I was waist deep in less than a second then slowed to a sinking rate of about 3 inches a second as I frantically clawed moss under my chest and arms. This stopped me going entirely under, but I would not have lasted more than a few hours. What saved me was the fact that I had by the greatest good fortune gone through by a small raft of peat and moss with several small willows growing on it. I managed to very gingerly work my way close enough to it and ease myself out, which was very difficult, and then crawled, like the monster from the black lagoon, back to the edge of the swamp. I was very lucky; if I had gone through several yards either way of that little patch of willows I would never have been able to hold on long enough to be found, especially since I was nearly two hours from the end of the nearest logging track. 
When he returned to the closest township, he learned that a man had gone missing in the same general area three weeks earlier. Atholl is a person with a strong sense of adventure, brimming with self-confidence and with good survival instincts, and his career has continued to be punctuated with occasional close shaves.

Following the research in Lapland, he submitted his doctoral dissertation in 1976 (Prehistoric competition and economic change in northern Sweden). This helped him to obtain his first academic post, at Auckland University during the 1977 academic year. At this time, he took his first steps into the tropical Pacific, to the southern Tongan island of 'Ata, as a member of the Royal Society of New Zealand's Southwest Pacific Expedition (1979b).

In 1978, he took up an appointment in the Anthropology Department, University of Otago, where he remained until 1993, progressing from assistant lecturer to a personal chair. He remarried soon after returning to Dunedin and Rosanne has been a staunch supporter of his research ever since, often accompanying him to remote parts of the Pacific. He and Rosanne have two children (Kirsten and John). He is a strong family man, devoted to his wife, three children and grandchildren.

The Otago period was an extremely productive one, not only as a researcher, but also as a teacher, supervising many thesis students and taking them on his own fieldwork expeditions. A great deal of Atholl's energy during this period was devoted to the Southern Hunters Project, which was focused on archaeological research in southern New Zealand, an area occupied by hunter-gatherers. However, he continued his Pacific interests with an expedition to the Kermadec Islands in 1978 (1981i). He later commented that this was his first experience of leading a team to a Pacific Island. His account of the crisis which arose when one of his assistants ate a poisonous plant makes hilarious reading, despite the gravity of the event (2004a:56-57).

The Southern Hunters Project involved excavations in no fewer than 20 archaeological



Figure 2. Atholl in the foreground at Shag River Mouth discussing strategy for excavation of the high-dune sequence, 1988-1989 (courtesy of Angela Boocock). 


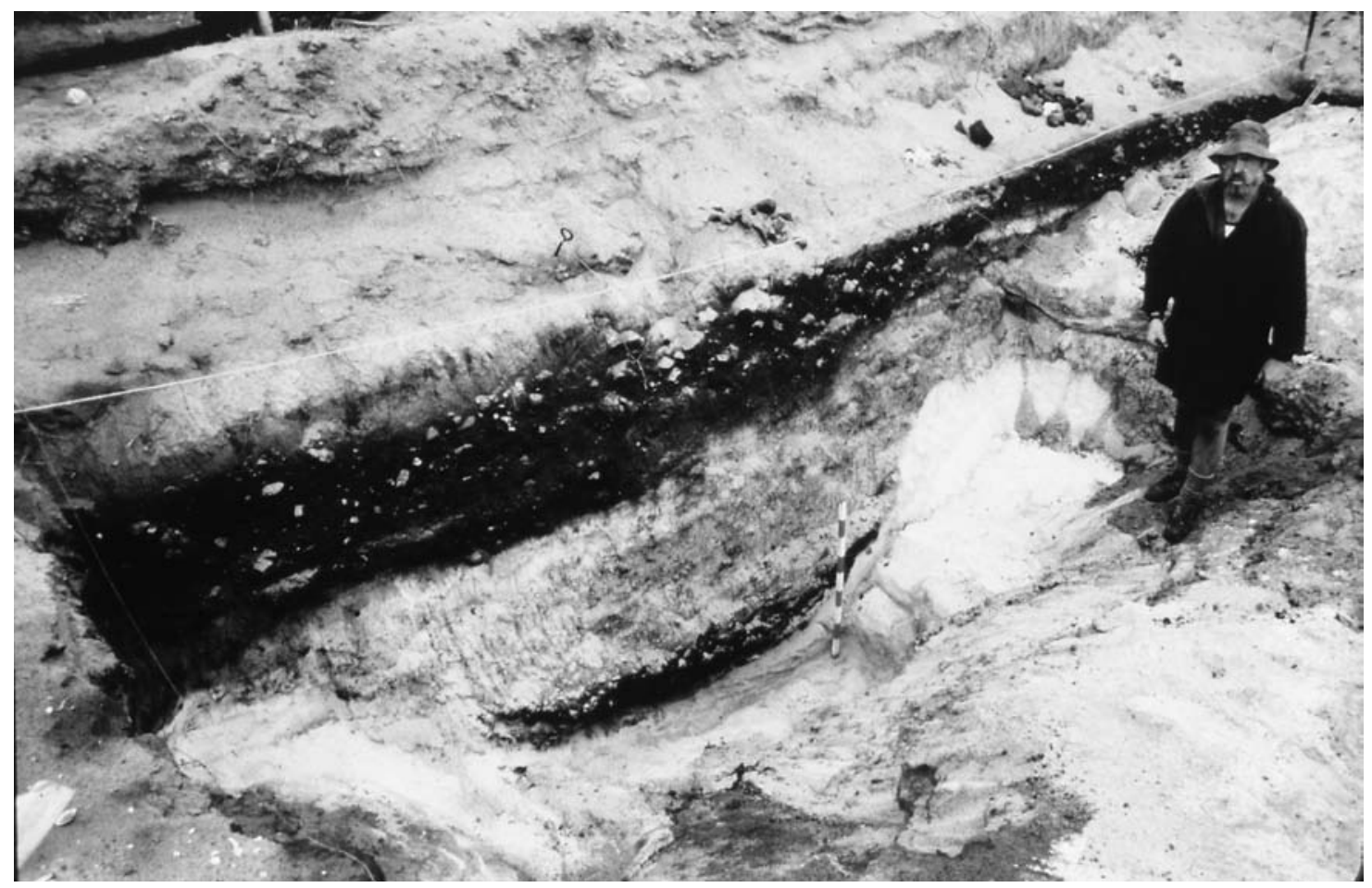

Figure 3. Atholl during excavation of the high dune at Shag River Mouth 1988-1989 (courtesy of lan Smith).

sites, revisiting places which had earlier seen excavation, and in many cases fossicking, as well as previously untouched sites. Arguably the most significant of these were Purakanui, Lee Island and Shag River Mouth, but they all contributed to a far better understanding of prehistoric life in southern New Zealand. The Purakanui excavations (1981a) took place close to his seaside home at the time. This research built on his interests in economic prehistory and the exploitation of the marine environment, begun earlier at Palliser Bay.

The three rock shelters on Lee Island in Lake Te Anau in Fiordland were newly discovered and contained a wealth of bird bones, fibre artefacts and other perishable remains. His analysis of the fibre remains involved a pioneering study of cordage and knots (Anderson et al. 1991b). The publication that resulted from the Lee Island excavations was his first major multi-authored work representing collaborative research (Anderson and McGovern-Wilson eds 1991), something that characterises much of his subsequent work. Atholl has always been a great team leader, inspiring others with the depth of his knowledge, good humour and personal charisma.

The excavations at Shag River Mouth, spread over four years, and subsequent analyses were once again collaborative, involving large numbers of students. Numerous uncontrolled excavations had been carried out at this site for more than a century, producing large quantities of artefacts and moa bones. It is a great credit to Atholl that he managed to find untouched stratigraphy, establish a chronology for this major southern site, and produce a substantive monograph (Anderson et al. eds 1996).

The Southern Hunters Project explored many aspects of prehistoric economics, but a major focus was inevitably on moa. During this period, Atholl produced his classic book Prodigious Birds: Moas and moa-hunting in prehistoric New Zealand (1989a), which has been reprinted as a paperback. This was a masterly and much-needed synthesis, covering historical, biological, chronological and cultural aspects of this famous New Zealand megafauna. It was a start to Atholl's ongoing interest in Pacific megafauna and extinctions. This work covered the whole of New Zealand and required a careful reappraisal of evidence from radiocarbon dating. The 


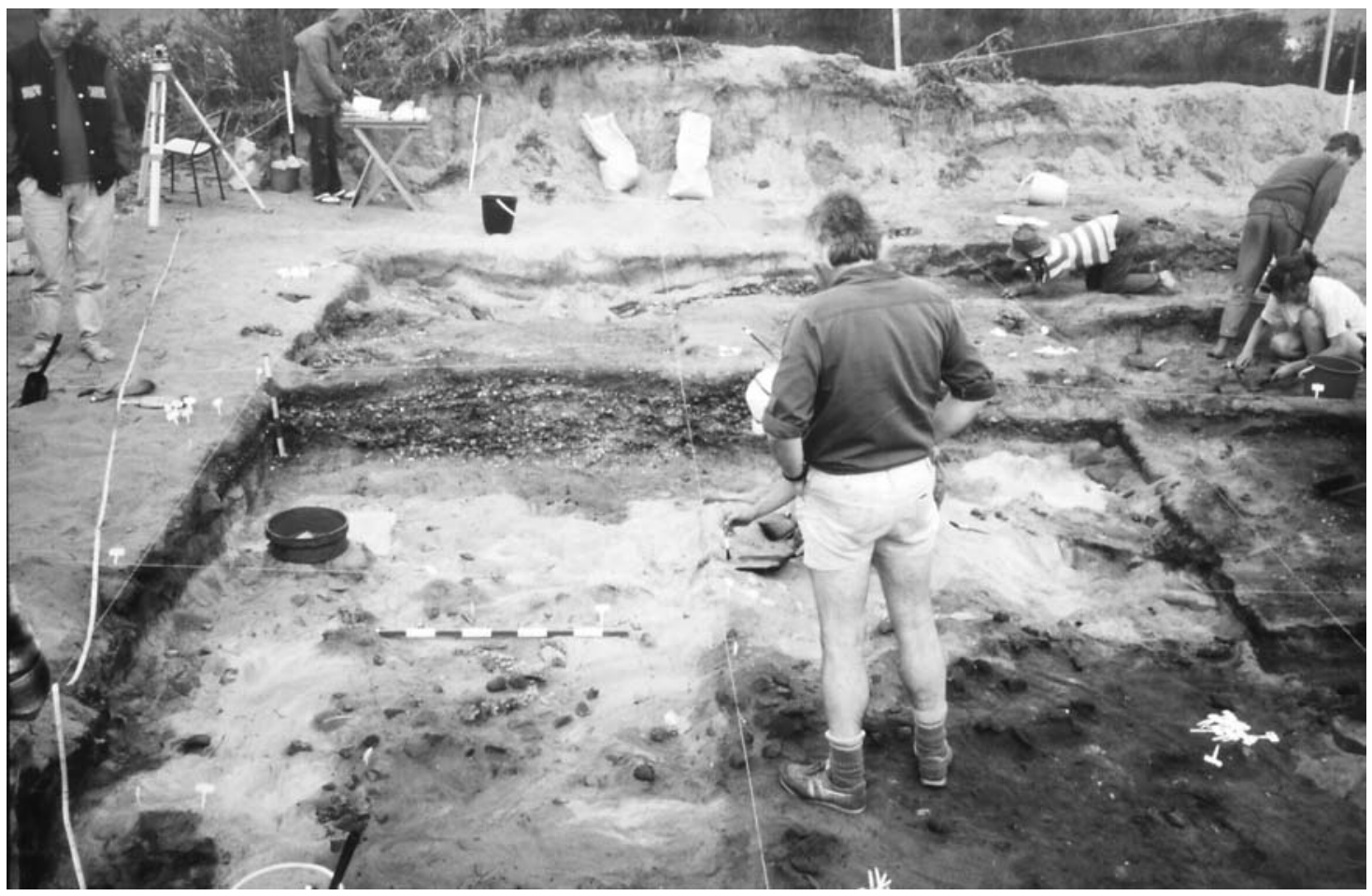

Figure 4. Atholl pondering the complexities of the high-dune excavation at Shag River Mouth 1988-1989 (courtesy of lan Smith).

deficiencies which were uncovered led him to review the chronology of colonisation in New Zealand and later to undertake re-dating of major moa-hunting sites, such as Houhora (Anderson and Wallace 1993) and Wairau Bar (Higham et al. 1999). Issues of chronology and dating have been of interest to him ever since.

Archaeology and polemics are no strangers to each other, and Atholl has never shied away from reasoned debate on controversial issues. His first major encounter arose when a colleague published an argument that New Zealand had been occupied at least twice the length of time of current orthodoxy. Atholl responded to this with a well-reasoned argument to the effect that if anything, the New Zealand chronology should be shortened, not lengthened (1991c). He carefully re-examined the entire history of radiocarbon dating in New Zealand, and re-evaluated the dating of many archaeological sites, not only for New Zealand, but for East Polynesia (Spriggs and Anderson 1993).

In all this, Atholl has displayed a dogged determination to get to the truth of any issue by focusing on quality of evidence and interpretation. Since the initial foray with moa chronology, refinement in dating has become a major preoccupation in Atholl's research. Probably the bestknown example of this is the controversy over radiocarbon dates of the small Polynesian rat, Rattus exulans, in New Zealand. Suggestions that this rat came to New Zealand with or without humans 2000 years ago have seen intensive research both for and against. Atholl has left no stone unturned to get to the truth and has been responsible for uncovering serious deficiencies in the initial accelerator dates. His publications on this topic have spanned eight years (1996h, 1997c, 1998d, 2000b, 2004h; Smith and Anderson 1998; Anderson and Higham 2004; Higham et al. 2004), again showing his determination to resolve this matter. The issue of short and long chronology is one which frequently arises in archaeology, most famously perhaps with the problem of Glozel in France, but the Pacific region has had its fair share of similar debate. In stressing the need for the highest quality of dating throughout the process, from sample selection from secure provenance and close documentation, to the finest laboratory methodology, Atholl 
has set aside the spectacular and been the champion of good scholarship. Throughout his career, he has steadfastly stressed the importance of interpretations arising from primary high-quality data and vigorously opposed speculative scenario building.

He has always been careful to distinguish what can and cannot be established by archaeological methods and by other disciplines which contribute to prehistory. A good example is his insistence that hypotheses based on one line of evidence must be tested against all available archaeological information. A typical case of this arose when it was proposed on the basis of pollen evidence that humans had arrived on Mangaia in the Cook Islands by the surprisingly early date of $2500 \mathrm{BP}$. Atholl showed that the pollen evidence alone could be interpreted in a number of ways, but was insufficient to overturn existing unambiguous archaeological evidence for a much shorter time scale (1994e).

Atholl has Scottish ancestry from his father, and through his mother he is descended from a branch of Ngai Tahu Maori from Rakiura (Stewart Island). When the Ngai Tahu placed a claim before the Waitangi Tribunal about historical grievances endured by their people from actions and inactions by the Crown, Atholl became a key researcher for the Ngai Tahu iwi (tribe). He gave a great deal of important evidence to the Waitangi Tribunal, clarifying difficult, highly contentious, historical issues. He has earned the greatest respect from both the Crown and Maori tribal authorities, not just for the depth of scholarship he brought to these hearings, but also for his balance and scrupulous honesty, even at times when his evidence ran counter to some tribal submissions. As a result, he has become a foremost authority on the ethnohistory of southern Maori, marshalling diverse historical documents into publishable form. An excellent example of this is Traditional lifeways of the southern Maori (1994 ed), an enormous task of

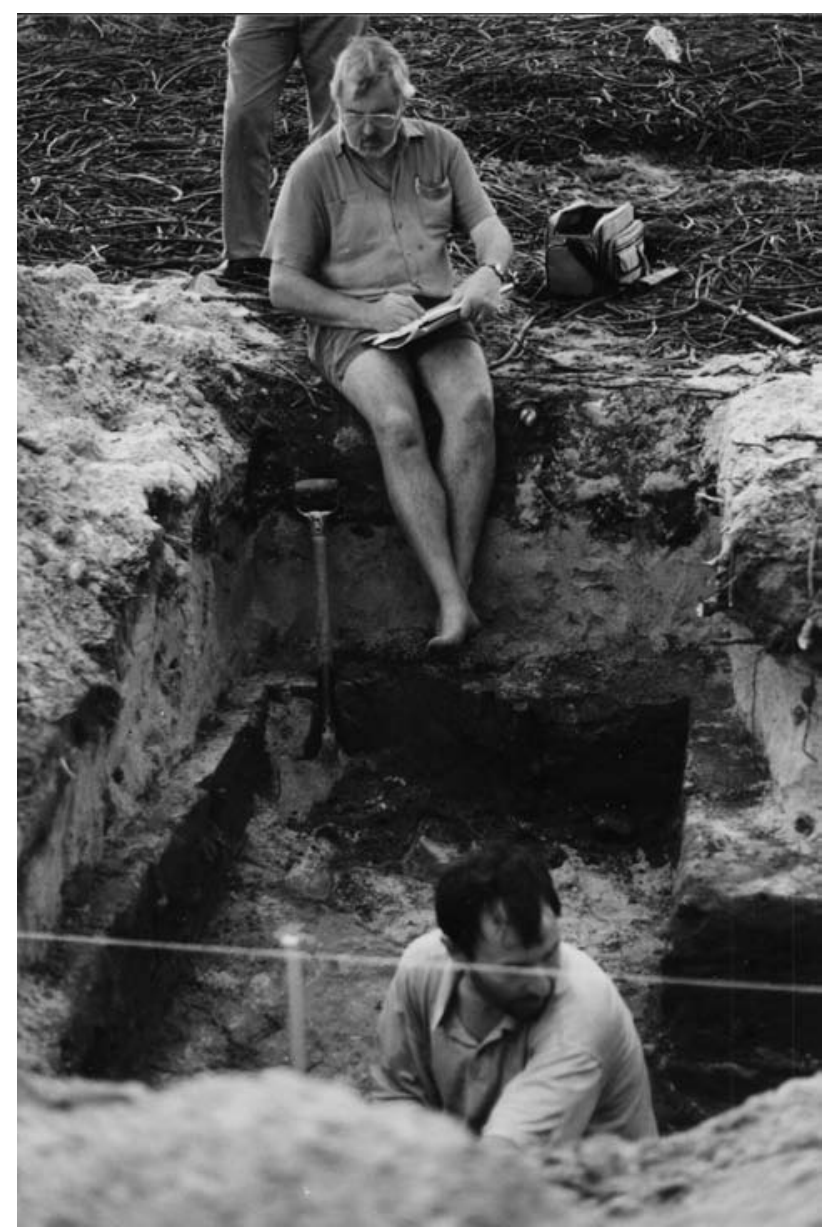

Figure 5. Atholl taking notes during the excavations at Emily Bay, Norfolk Island, 1996 (courtesy of lan Smith). 
editorial work definitely not for the faint hearted. In these endeavours, Atholl also managed to bridge the gap between deep scholarship and publications for a wider audience, such as When all the moa ovens grew cold (1983a), Te Puoho's last raid: the battle of Tuturau, 1836-1837 (1986d), and The welcome of strangers (1998a). The Ngai Tahu settlement with the Crown following the Waitangi Tribunal hearings has been among the most successful of recent times, and Atholl made an important contribution towards this outcome. He also contributed a number of biographies of southern Maori to the Dictionary of New Zealand Biography, including one on his ancestress Anne Wharetutu Newton (1990f).

In 1993, Atholl and his family moved to Canberra, where he took up the Establishment Chair of Prehistory at the Research School of Pacific and Asian Studies, Australian National University. This post offered new opportunities for research throughout the Pacific basin and rim, both for himself and for students under his supervision. His numerous fieldwork expeditions have taken him to Niue, Fiji, Norfolk, Lord Howe, Tuvalu, Maupiti, Kiritimati Island (Kiribati), Palau, Taiwan, Philippines, Juan Fernandez, Mangareva, Rapa, Christmas Island (Indian Ocean), New Caledonia, Yaeyama Islands (Japan), Galapagos Islands, Mocha Island (Chile), and Huahine. Some of these are extremely isolated places and reflect Atholl's desire to investigate the remotest limits of prehistoric exploration of the Pacific.

These expeditions took place within the framework of two major projects: the Indo-Pacific Colonisation Project, and the Asian Fore-Arc Project, and have resulted in many scholarly publications and lecture series. Collaborative monographs have been produced on Norfolk Island (Anderson and White eds 2001), Niue (Walter and Anderson 2002) and Kiritimati (Anderson et al. 2000c). Volumes on Rapa (Anderson and Kennett eds nd) and Fiji (Clark and Anderson eds nd) are forthcoming.

This period of research in Canberra has been immensely productive. Besides carrying out and publishing fundamental archaeological research in various parts of the Pacific, Atholl has pursued a number of interrelated themes centering on colonisation and the sustainability of settlement on small islands. Island sequences and the chronology of initial settlement of islands have been continuing concerns (2000e, 2005a; Spriggs and Anderson 1993; Anderson and Clark 1999; Anderson and Sinoto 2002; Anderson et al. 2003a; Phear et al. 2004). He has made major contributions not just towards the facts of migration and dispersal, but towards suggestions of causes for these events (1995a, 2001a, 2003b, 2004b, 2006b), and has highlighted issues of isolation, remoteness and abandonment (2001b, 2005b).

Atholl's interest in birds, megafauna and extinctions has resulted in reports of fossil fauna and new bird species from Niue (Steadman et al. 2000; Worthy et al. 2002), and the important discovery of extinct megafauna in Fiji (Worthy et al. 1999; Anderson et al. 2001a). His excavations in the Volivoli caves inland from Sigatoka in 1998 uncovered a previously unknown extinct crocodile, which was named after him - Volia athollandersoni - and features on the Fijian 50c stamp. He has also considered wider issues of faunal collapse and landscape change on Pacific islands (2002b, 2007a).

A keen yachtsman himself, Atholl has contributed significantly to discussion of voyaging strategies (1996a) and the development and capabilities of Pacific voyaging canoes (2000d, 2001d), and considered the effects of La Niña and El Niño on Pacific migrations (Anderson $e t$ al. 2006a).

Throughout this period in Canberra, he has continued to publish extensively on New Zealand archaeological topics. In 1998, he launched the Southern Margins Project, organising expeditions to Rakiura (Stewart Island), New Zealand's Subantarctic Islands, and Whenua Hou (Codfish Island) off Stewart Island. This project built on Atholl's earlier research in the 


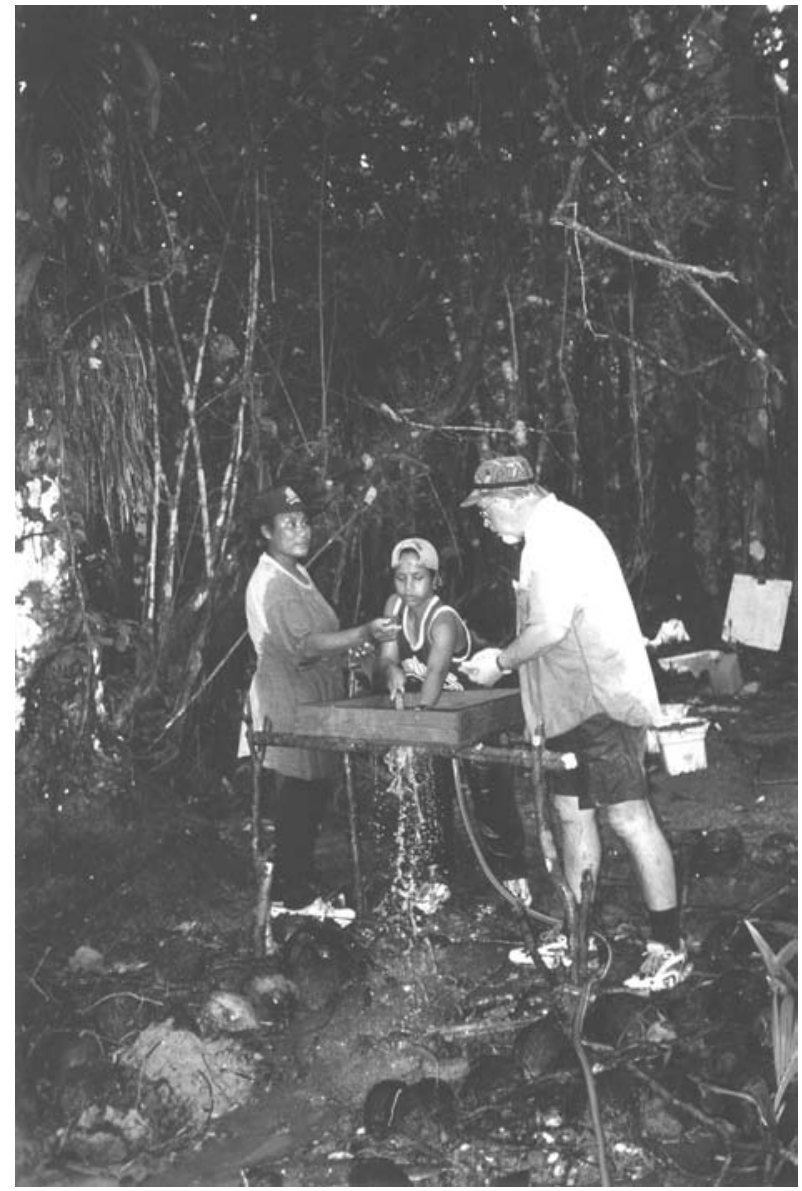

Figure 6. Atholl wet sieving during excavations in Palau, 2000 (courtesy of Geoffrey Clark).

Kermadecs and Norfolk Island, as well as New Zealand, and showed that Polynesian voyaging had extended into the sub-polar region some 700 years ago (Anderson and O'Regan 2000; Anderson 2005d). Atholl was thus able to extend his definition of 'South Polynesia' to include not only Norfolk, the Kermadecs, the two main islands of New Zealand, the Chatham Islands and Rakiura, but also the Auckland Islands.

One might think that someone who has devoted so much energy to his own personal research and publications would have had little time for advancing the careers of others. The opposite is the case with Atholl. He has been a dedicated teacher throughout his career, supervising many thesis students at both the University of Otago and Australian National University, and has helped students from other countries too. But his generosity towards others does not stop there - over the years, he has also accepted the thankless task of serving on a variety of university committees, the New Zealand Historic Places Trust, and many editorial boards, and acted as advisor to Te Runanga o Ngai Tahu, and as a referee for diverse granting agencies. He has always been a prompt and insightful referee of manuscripts submitted for publication in journals and books. He has helped numerous colleagues over the difficult hurdles of promotion in academic institutions by giving personal and professional assistance, and has gone out of his way to promote people for awards, honorary positions and degrees.

A typical example of his generosity towards others was the festschrift for Ron Scarlett, which he initiated in 1976 before his doctorate was completed. Ron was a person whose contribution behind the scenes, identifying bird bones from archaeological sites, might otherwise have gone unnoticed (ed 1979). Not all those he approached for contributions felt that such an accolade was justified, but Atholl correctly recognised that people like Ron provided extremely important 


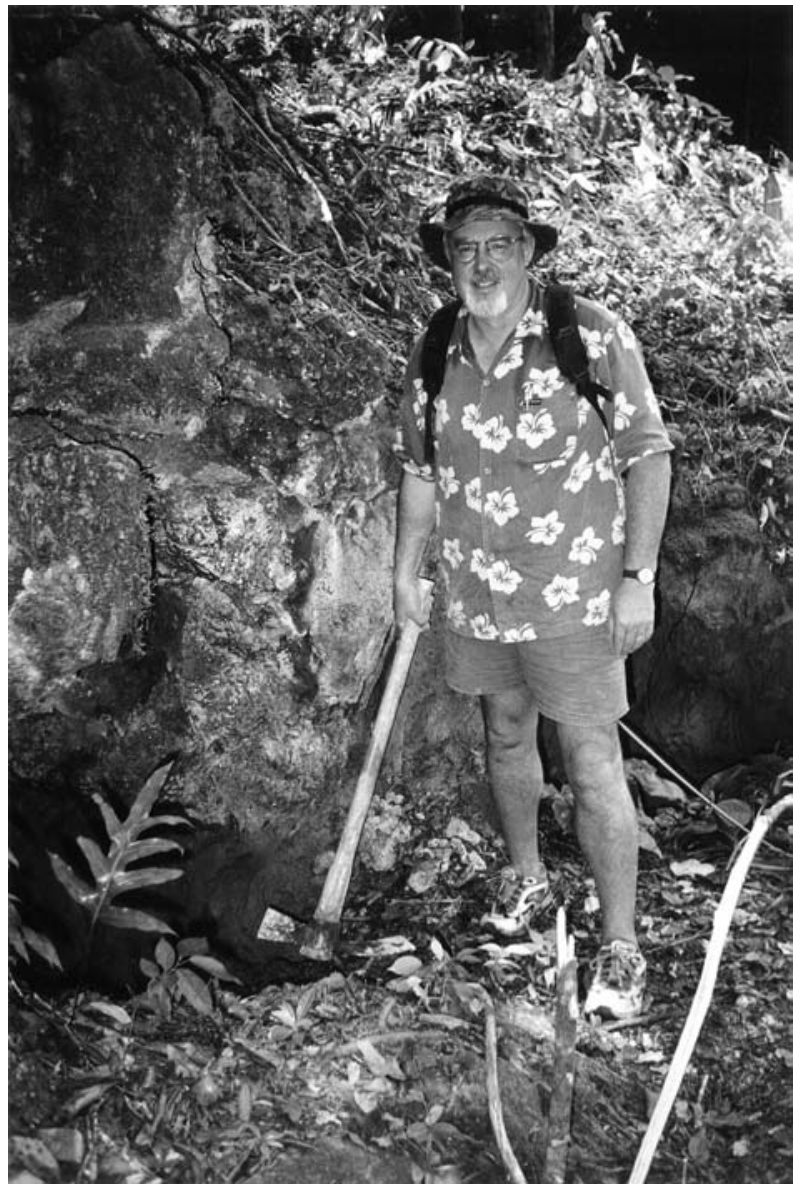

Figure 7. Atholl during fieldwork in Palau 2000 (courtesy of Geoffrey Clark).

basic data, without which archaeology would be the poorer. The volume was well supported and a valuable contribution to knowledge resulted. This was the first of several festschrifts of which he was an invaluable organiser, and was followed by those for Jim Allen (Anderson and Murray eds 2000), Rhys Jones (Anderson et al. eds 2001), and Janet Davidson (Anderson et al. eds 2007).

Not surprisingly, his own contributions to knowledge have been widely recognised. His awards include Fellow of the Royal Society of New Zealand (1991), Fellow of the Australian Academy of the Humanities (1996), Fellow of the Society of Antiquaries of London (2002), Doctorate of Science University of Cambridge (2002), Federation Medal of Australia for services to archaeology (2001), and Companion of the New Zealand Order of Merit for services to archaeology and anthropology (2005). He has often been invited to give keynote addresses and has held visiting fellowships at numerous academic institutions around the world.

From a very young age, Atholl displayed enthusiasm for many outdoor pursuits: tramping in the forests of New Zealand, hunting deer, skiing, sailing and mountaineering. On one spectacular occasion, he had a near miss on Mount Windward at $2000 \mathrm{~m}$, slithering $500 \mathrm{~m}$ down a near-vertical ice slope in winter before coming to a halt on the brink of a bluff. He was 17 years old at the time, but this event did not put him off mountaineering. He went on to conquer some quite demanding peaks as an adult. He also developed an abiding interest in diverse fishing activities: scuba diving, spear fishing, dragging nets for flounders, whitebaiting, surf casting and fly fishing. Not all of his professional colleagues may fully appreciate just how strong the 'call of the wild' is for him, so this sketch of 'Atholl the academic' should be rounded off with some comments on this other side to his character. 


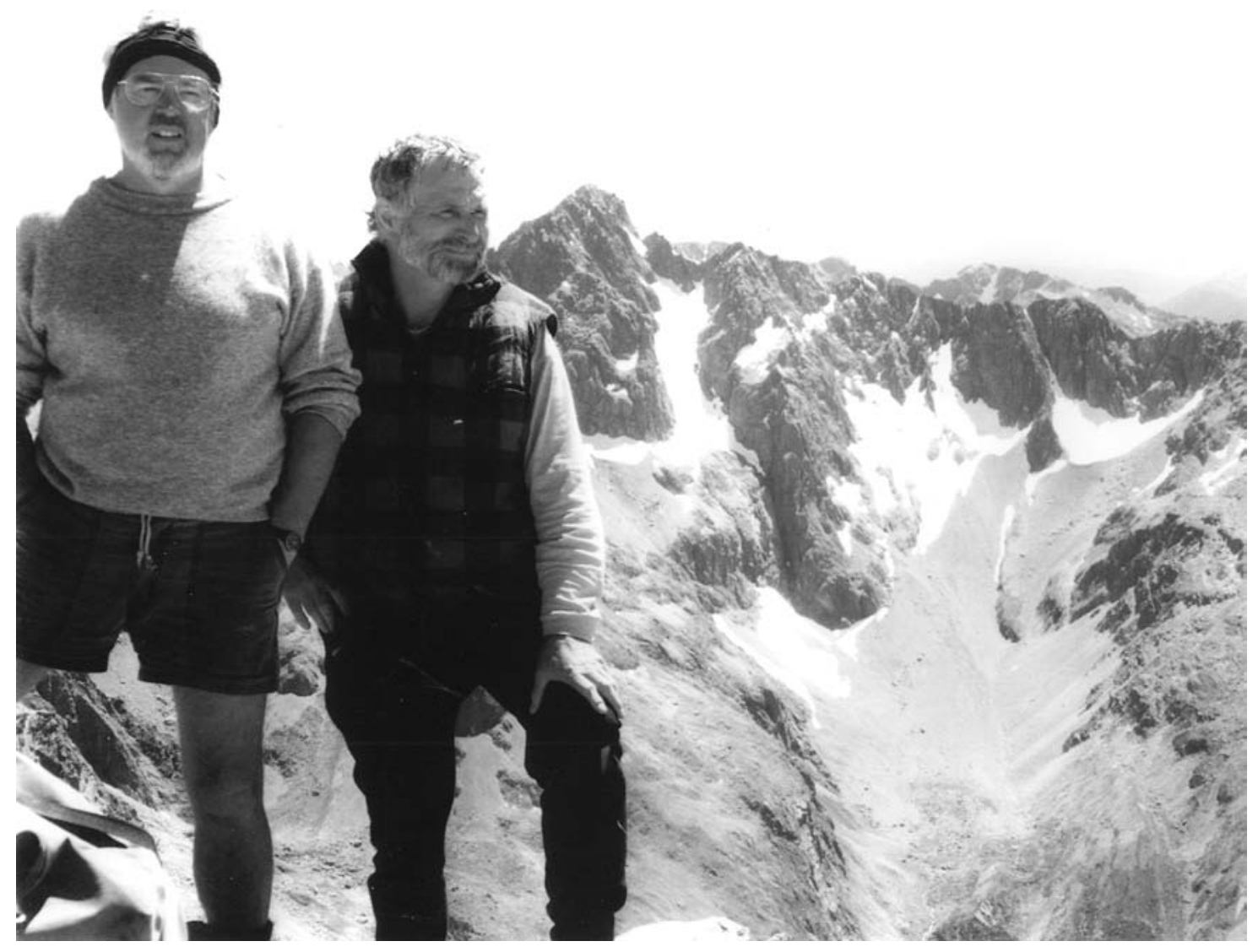

Figure 8. Atholl has been a keen mountaineer since school days. Here, he is with Barry Clark on the summit of Mt Cupola, Nelson Lakes National Park, 1998 (courtesy of Barry Clark).

In whatever part of the world he travels, he characteristically seeks out every opportunity to explore the nearby environment, whether mountain, forest, river or sea: fly fishing for grayling in the ice lakes of Alaska, long-line fishing in the cold Subantarctic waters of the Auckland Islands, catching halibut in the seas around Kachemak Bay (Alaska), sailing chartered yachts around the Stockholm archipelago in the Baltic Sea, the inner Hebrides of Scotland, or Tuvalu in the tropical Pacific, and sailing his own yacht Cepheus in the Marlborough Sounds in New Zealand. When he lived in Dunedin, he was often seen windsurfing on the harbour, especially when high winds forced all but the bravest off the water. This lifestyle has not been without its mix of adventures, including breaking an arm skiing in Japan, and breaking a foot site-surveying at Murdering Beach in Otago. In another life, Atholl may well have been an explorer. As it is, he has combined the best things of two worlds, academic and outdoors, equally at home in both.

Atholl is due to retire in 2008 and take up residence in a property right in the centre of the richest vineyards of the Wairau Valley in New Zealand, surrounded on all sides by grapes of one of his favourite wines, Marlborough sauvignon blanc. One corner of his property adjoins the icy cold waters of Spring Creek, famous for prize-winning brown trout. What better way to fill out the years ahead than by writing books close to the very best things of life - mountains, forest, clear rivers, and the sea. 


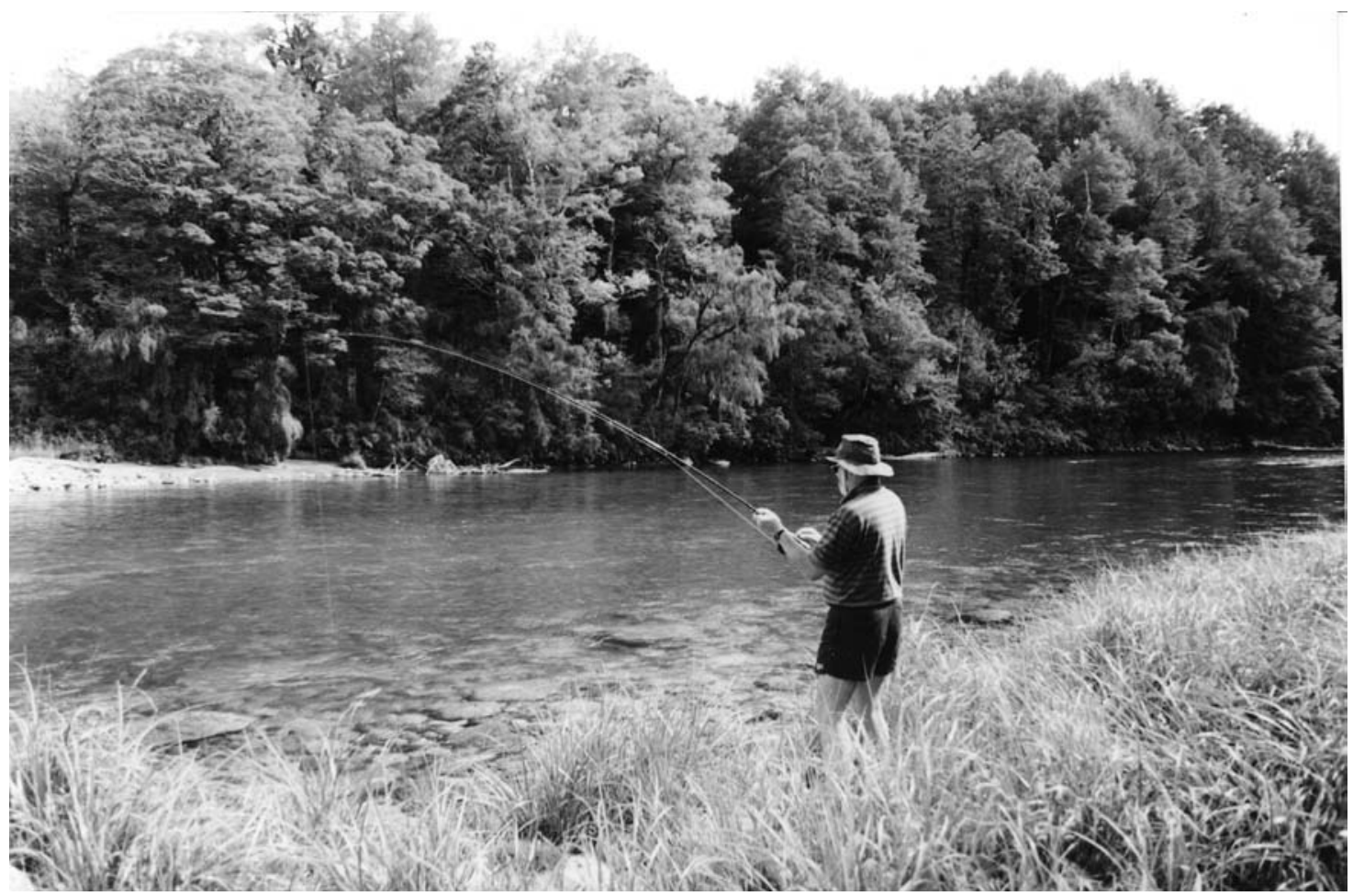

Figure 9. Atholl's deep knowledge of all aspects of fishing follows a lifetime's interest in fly fishing in remote parts of the world. Maruia River, New Zealand, 2002 (courtesy of Barry Clark).

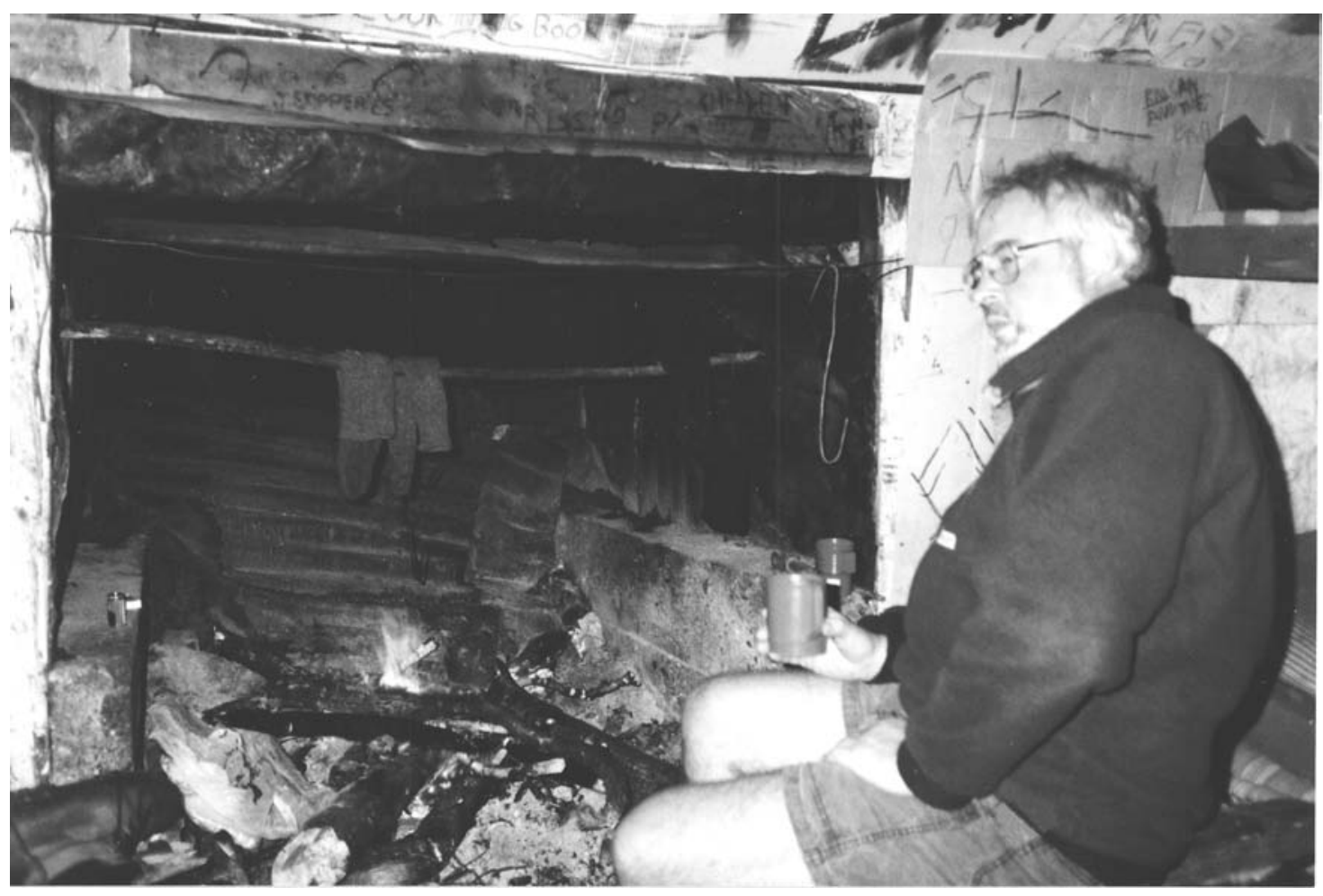

Figure 10. For Atholl, one of the great pleasures of life is unwinding by the camp fire at the end of a day's tramping. Taken at Downie's hut, Matakitaki River, Nelson Lakes National Park, 1993 (courtesy of Barry Clark). 


\section{Publications of Atholl John Anderson}

Excluding book reviews, consultancy reports, unpublished seminars and public lectures, conference papers and reprints.

1972 Anderson, A.J. and N.J. Prickett. Radiocarbon dates for the Wairarapa IV. New Zealand Archaeological Association Newsletter 15:164.

1973a Anderson, A.J. A critical evaluation of the methodology of midden sampling. New Zealand Archaeological Association Newsletter 16:119-127.

1973b Anderson, A.J. The conchiolin dating method. New Zealand Journal of Science $16: 553-558$.

1973 Anderson, A.J. and D.G. Sutton. Archaeology of Mapoutahi Pa, Otago. New Zealand Archaeological Association Newsletter 16:107-118.

1974 Leach, B.F. and A.J. Anderson. The transformation of an estuarine to a lacustrine environment in the lower Wairarapa. Journal of the Royal Society of New Zealand $4: 267-275$.

1978 Anderson, A.J. The role of a competition model in the archaeological explanation of economic change, in D. Green, C. Hazelgrove and M. Spriggs (eds), Social Organisation and Settlement: contributions from anthropology, archaeology and geography, pp. 31-45. British Archaeological Reports (Oxford) International Series 47.

1978 Leach, B.F. and A.J. Anderson. The prehistoric sources of Palliser Bay obsidian, Journal of Archaeological Science 5:301-307.

1979 Anderson, A.J. (ed), Birds of a Feather: osteological and archaeological papers from the South Pacific in honour of R.J. Scarlett. British Archaeological Reports (Oxford) International Series 62.

1979a Anderson, A.J. Introduction, in A.J. Anderson (ed), Birds of a Feather: osteological and archaeological papers from the South Pacific in honour of R.J. Scarlett, pp. i-v. British Archaeological Reports (Oxford) International Series 62.

1979b Anderson, A.J. Archaeological explorations on Ata Island, Tonga, in Lau-Tonga 1977. Royal Society of New Zealand Bulletin 17:1-21.

1979c Anderson, A.J. Excavations at the Archaic site at Waianakarua Mouth, north Otago, New Zealand Archaeological Association Newsletter 22:156-162.

1979d Anderson, A.J. Excavations at the Hawksburn moa-hunting site: an interim report, New Zealand Archaeological Association Newsletter 22:48-59.

1979e Anderson, A.J. Prehistoric exploitation of marine resources at Black Rocks point, Palliser Bay, in B.F. Leach and H.M. Leach (eds), Prehistoric Man in Palliser Bay, pp. 49-65. National Museum Bulletin 21.

1979f Anderson, A.J. The 1978 Raoul Island archaeological expedition: an interim report, New Zealand Archaeological Association Newsletter 22:76-82.

1979a Leach, B.F. and A.J. Anderson. Prehistoric exploitation of crayfish in New Zealand, in A.J. Anderson (ed), Birds of a Feather: osteological and archaeological papers from the South Pacific in honour of R.J. Scarlett, pp. 141-161. British Archaeological Reports (Oxford) International Series 62. 
1979b Leach, B.F. and A.J. Anderson. 1979 The role of labrid fish in the prehistoric economies of New Zealand, Journal of Archaeological Science 6:1-15.

1980a Anderson, A.J. Re-discovery of a moa-hunting site in the Old Man Range, New Zealand Archaeological Association Newsletter 23:169-172.

$1980 \mathrm{~b}$ Anderson, A.J. Towards an explanation of prehistoric social organisation and settlement patterns amongst the southern Ngai Tahu, New Zealand Journal of Archaeology 2:3-23.

1981a Anderson, A.J. A fourteenth century fishing camp at Purakanui Inlet, Otago, Journal of the Royal Society of New Zealand 11:201-221.

1981b Anderson, A.J. A lure hook shank from Shag River Mouth, Otago, New Zealand Archaeological Association Newsletter 24:280-282.

1981c Anderson, A.J. A model of prehistoric collecting on the rocky shore, Journal of Archaeological Science 8:109-120.

1981d Anderson, A.J. Archaeological sites at Aramoana, Otago Harbour, New Zealand Archaeological Association Newsletter 24:92-97.

1981e Anderson, A.J. Economic change and the prehistoric fur trade in northern Sweden: the relevance of a Canadian model, Norwegian Archaeological Review 14:1-38.

$1981 \mathrm{f}$ Anderson, A.J. Pre-European hunting dogs in the South Island, New Zealand, New Zealand Journal of Archaeology 3:15-20.

$1981 \mathrm{~g}$ Anderson, A.J. Radiocarbon dates for Archaic sites at Purakanui and Hawksburn, New Zealand Archaeological Association Newsletter 24:63-64.

$1981 \mathrm{~h}$ Anderson, A.J. The archaeology of moa-hunting in southern New Zealand, Calgary Archaeologist 8/9:8-10.

1981i Anderson, A.J. The archaeology of Raoul Island and its place in the settlement history of Polynesia, Archaeology and Physical Anthropology in Oceania 15:131-141.

1981j Anderson, A.J. The value of high-latitude models in south Pacific archaeology: a critique, New Zealand Journal of Archaeology 3:143-160.

1981 Anderson, A.J. and N.A. Ritchie. Excavations at the Dart bridge site, Upper Wakatipu region, New Zealand Archaeological Association Newsletter 24:5-10.

1982a Anderson, A.J. A review of economic patterns during the Archaic phase in southern New Zealand, New Zealand Journal of Archaeology 4:45-75.

1982b Anderson, A.J. Barracouta fishing in prehistoric and protohistoric New Zealand, Journal de la Société des Océanistes 72-73:145-158.

1982c Anderson, A.J. Central Norrland. In M. Jarman, G. Bailey and H. Jarman (eds), Early European Agriculture: its foundation and development, pp. 114-120. Cambridge University Press.

1982d Anderson, A.J. Comment on convergent cultural adaptation in the subantarctic zone. Current Anthropology 23:87.

1982e Anderson, A.J. Further comment and reply to Selinge. Norwegian Archaeological Review 15:124-125. 
$1982 \mathrm{f}$ Anderson, A.J. Habitat preferences of moa in central Otago, A.D. 1000-1500 according to palaeobotanical and archaeological evidence. Journal of the Royal Society of New Zealand 12:321-336.

$1982 \mathrm{~g}$ Anderson, A.J. Maori settlement in the interior of southern New Zealand from the early eighteenth to the late nineteenth centuries A.D. Journal of the Polynesian Society 91:53-80.

1982h Anderson, A.J. North and Central Otago. In N.J. Prickett (ed), The First Thousand Years: Regional perspectives in New Zealand archaeology, pp. 114-120. Dunmore Press, Palmerston North.

$1982 \mathrm{i}$ Anderson, A.J. The Otokia mouth site at Brighton Beach, Otago. New Zealand Archaeological Association Newsletter 25:47-52.

1982j Anderson, A.J. West Coast, South Island. In N.J. Prickett (ed), The First Thousand Years: Regional perspectives in New Zealand archaeology, pp. 103-112. Dunmore Press, Palmerston North.

1983a Anderson, A.J. When All the Moa Ovens Grew Cold: Nine centuries of changing fortune for the southern Maoris. Otago Heritage Books, Dunedin.

$1983 \mathrm{~b}$ Anderson, A.J. Analysis of fish remains from southern Fiordland and Stewart Island. New Zealand Archaeological Association Newsletter 26:264-270.

1983c Anderson, A.J. Excavations at Mapoutahi Pa, Otago. University of Otago Anthropology Department Working Papers No. 1.

1983d Anderson, A.J. Faunal depletion and subsistence change in the early prehistory of southern New Zealand. Archaeology in Oceania 18:1-10.

1983e Anderson, A.J. Maori wooden bowls from Central Otago. In S. Bulmer, G. Law and D. Sutton (eds), A Lot of Spadework to be Done: essays in honour of Lady Aileen Fox, pp. 129-142. New Zealand Archaeological Association Monograph 14.

$1983 \mathrm{f}$ Anderson, A.J. Moa-hunting in the high country of southern New Zealand. In J. Clutton-Brock and C. Grigson (eds), Animals and Archaeology Volume 2, pp. 33-52. British Archaeological Reports (Oxford) International Series 83.

1984 Anderson, A.J. The extinction of moa (Aves: Dinornithidae) in southern New Zealand. In P.S. Martin and K.G. Klein (eds), Quaternary Extinctions, pp. 728-740. University of Arizona Press.

1984 Anderson, A.J. and N.A. Ritchie. Preliminary report on test excavations at a newly discovered moahunting site at Coal Creek, Central Otago. New Zealand Archaeological Association Newsletter 27:174-180.

1985 Anderson, A.J. The Scandinavian colonisation of the north Swedish interior, 500-1500 A.D. In S. Dyson (ed), Comparative Studies in the Archaeology of Colonialism, pp. 38-52. British Archaeological Reports (Oxford) International Series 233.

1986 Anderson, A.J. (ed), Traditional Fishing in the Pacific: Ethnographical and archaeological papers from the 15th Pacific Science Congress. Pacific Anthropological Records 37. Bishop Museum, Honolulu. 
1986a Anderson, A.J. Introduction. In A.J. Anderson (ed), Traditional Fishing in the Pacific: Ethnographical and archaeological papers from the 15th Pacific Science Congress, pp. ix-xi. Pacific Anthropological Records 37. Bishop Museum, Honolulu.

1986b Anderson, A.J. Mahinga ika o te moana: selection in the pre-European fish catch of southern New Zealand. In A.J. Anderson (ed), Traditional Fishing in the Pacific: Ethnographical and archaeological papers from the 15th Pacific Science Congress, pp. 151-165. Pacific Anthropological Records 37. Bishop Museum, Honolulu.

1986c Anderson, A.J. Makeshift structures of little importance: a reconsideration of Maori dwellings with reference to the round hut. Journal of the Polynesian Society 95:91-114.

1986d Anderson, A.J. Te Puoho's Last Raid: the battle of Tuturau, 1836-1837. Otago Heritage Books, Dunedin.

1986e Anderson, A.J. The Maori in Fiordland. In C. McMillan and B. Turner (eds), Mountains of Water: the story of Fiordland National Park, pp. 82-85. Lands and Survey Department, Wellington.

1986 Anderson, A.J. and N.A. Ritchie. Pavements, pounamu and ti: the Dart Bridge site, western Otago. New Zealand Journal of Archaeology 8:115-141.

1986 Leach, F., A. Anderson, D. Sutton, R. Bird, P. Duerden and E. Clayton. The origin of prehistoric obsidian artefacts from the Chatham and Kermadec Islands. New Zealand Journal of Archaeology 8:143-170.

1987a Anderson, A.J. Hunting and fishing. In J. Wilson (ed), From the Beginning: the archaeology of the Maori, pp. 73-84. Penguin Books, Auckland.

$1987 \mathrm{~b}$ Anderson, A.J. Recent developments in Japanese prehistory; a review. Antiquity 61:270-281.

1987c Anderson, A.J. Recent uplift at Raoul Island, Kermadec Group, Southwest Pacific. New Zealand Journal of Geology and Geophysics 30:325-327.

1987d Anderson, A.J. Supertramp science: some thoughts on archaeometry and archaeology in Oceania. In W.R. Ambrose and J.M.J. Mummery (eds), Archaeometry: Further Australasian studies, pp. 3-18. Research School of Pacific Studies, Australian National University, Canberra.

1987e Anderson, A.J. The first recorded name for Moa. Journal of the Royal Society of New Zealand 17:421-422.

1988a Anderson, A.J. Coastal subsistence economies in prehistoric coastal New Zealand. In G.N. Bailey and J.E. Parkington (eds), The Archaeology of Hunter-Gatherer Subsistence Economies in Coastal Environments, pp. 93-101. Cambridge University Press.

1988b Anderson, A.J. Moa extinctions in Southern New Zealand: a reply to Sutton. Archaeology in Oceania 23:98-99.

1988c Anderson, A.J. Prehistoric fowling in the Nothofagus forest of southern New Zealand. Archaeozoologia: Revue Internationale d'Archéologie II(1/2):201-207.

$1988 \mathrm{~d}$ Anderson, A.J. The art of concealment: Maori rock art in the South Island. Ka Tuhitubi o Nehera, pp. 4-8. National Museum Publication, Wellington. 
1988 Anderson, A.J. and B. McFadgen. Return voyaging from New Zealand to East Polynesia. In C. Cristino, P. Vargas, R. Izaurieta and R. Budd (eds), First International Congress, Easter Island and East Polynesia, Volume 1: Archaeology, pp. 13-23. Universidad de Chile.

1989a Anderson, A.J. Prodigious Birds: moas and moa-hunting in prehistoric New Zealand. Cambridge University Press.

1989b Anderson, A.J. A diary discovered: Bayard Booth on Shag Mouth. In D.G. Sutton (ed), Saying So Doesn't Make It So: Essays in honour of B. Foss Leach, pp. 64-75. New Zealand Archaeological Association Monograph 17.

1989c Anderson, A.J. Mechanics of overkill in the extinction of New Zealand Moas. Journal of Archaeological Science 16:137-151.

1989d Anderson, A.J. On evidence for the survival of moa in European Fiordland. New Zealand Journal of Ecology 12(Supplement):39-44.

1989e Anderson, A.J. The beast without: moa as colonial frontier myths in New Zealand. In R. Willis (ed), Signifying Animals: human meaning in the natural world, pp. 236-245. One World Archaeology Series. Unwin and Hyman, London.

1990a Anderson, A.J. A record of 1000 years of the unwritten past. Historic Places 28:5-10.

1990b Anderson, A.J. Comment on T.F. Flannery: Pleistocene Faunal Loss. Archaeology in Oceania 25(2):63-64.

1990c Anderson, A.J. Kuri. In C.M. King (ed), The Handbook of New Zealand Mammals, pp. 280-287. Oxford University Press, Auckland.

1990d Anderson, A.J. The Last Archipelago: 1000 years of Maori settlement in New Zealand. In A. Anderson, J. Binney, D. Hamer, R. Dalziel, E. Olsen, W.H. Oliver and J. Phillips, Towards 1990: Seven leading historians examine significant aspects of New Zealand history, pp. 1-19. Government Printer, Wellington.

1990e Anderson, A.J. Edward Shortland 1812-1893. In W. Oliver (ed), Dictionary of New Zealand Biography, Volume One 1769-1869, pp. 394-397. Allen and Unwin and Department of Internal Affairs, Wellington.

$1990 \mathrm{f}$ Anderson, A.J. Anne Wharetutu Newton fl.1827-1870. In W. Oliver (ed), Dictionary of New Zealand Biography, Volume One 1769-1869, pp. 308-309. Allen and Unwin and Department of Internal Affairs, Wellington.

1990g Anderson, A.J. Te Puoho-o-te-rangi ?-1836/1837. In W. Oliver (ed), Dictionary of New Zealand Biography, Volume One 1769-1869, pp 483-484. Allen and Unwin and Department of Internal Affairs, Wellington.

1990h Anderson, A.J. Te Huruhuru ?-1861. In W. Oliver (ed), Dictionary of New Zealand Biography, Volume One 1769-1869, pp. 454-455. Allen and Unwin and Department of Internal Affairs, Wellington.

1990i Anderson, A.J. Topi Patuki 1810-20-1900. In W. Oliver (ed), Dictionary of New Zealand Biography, Volume One 1769-1869, pp. 337-338. Allen and Unwin and Department of Internal Affairs, Wellington. 
1990j Anderson, A.J. Te Whakataupuka fl. 1826-1834. In W. Oliver (ed), Dictionary of New Zealand Biography, Volume One 1769-1869, pp. 520-521. Allen and Unwin and Department of Internal Affairs, Wellington.

1990k Anderson, A.J. Hone Tuhawaiki ?-1844. In W. Oliver (ed), Dictionary of New Zealand Biography, Volume One 1769-1869, pp. 553-555. Allen and Unwin and Department of Internal Affairs, Wellington.

1990 Anderson, A.J. and B. McFadgen. Prehistoric two-way voyaging between New Zealand and East Polynesia: Mayor Island obsidian on Raoul Island and possible Raoul Island obsidian in New Zealand. Archaeology in Oceania 25:37-42.

1990 Anderson, A.J. and R. McGovern-Wilson. The pattern of prehistoric colonisation in New Zealand. Journal of the Royal Society of New Zealand 20:41-63.

1991a Anderson, A.J. Current research issues in the study of moas and moa-hunting. In B. McFadgen and P. Simpson (eds), Research Directions for Conservation Science, pp. 17-29. Science and Research Series 37. Department of Conservation, Wellington.

1991b Anderson, A.J. Race Against Time: the early Maori-Pakeha families and the development of the mixed-race population in southern New Zealand. Hocken Lecture 1990. Hocken Library, University of Otago.

1991c Anderson, A.J. The chronology of colonization in New Zealand. Antiquity 65:767-795.

1991d Anderson, A.J. Rockshelter excavations and radiocarbon chronology. In A.J. Anderson and R. McGovern-Wilson (eds), Beech Forest Hunters: the archaeology of Maori rockshelter sites on Lee Island, Lake Te Anau, in southern New Zealand, pp. 9-17. New Zealand Archaeological Association Monograph 18.

1991e Anderson, A.J. Implements in stone and bone. In A.J. Anderson and R. McGovernWilson (eds), Beech Forest Hunters: the archaeology of Maori rockshelter sites on Lee Island, Lake Te Anau, in southern New Zealand, pp. 18-28. New Zealand Archaeological Association Monograph 18.

1991 Anderson, A.J. and M. McGlone. Living on the edge: prehistoric land and people in New Zealand. In J. Dodson (ed), The Naive Lands: Human-environmental interactions in Australia and Oceania, pp. 199-241. Longman Cheshire, Sydney.

1991 Anderson, A.J. and R. McGovern-Wilson (eds), Beech Forest Hunters: the archaeology of Maori rockshelter sites on Lee Island, Lake Te Anau, in southern New Zealand. New Zealand Archaeological Association Monograph 18.

1991 Anderson, A.J. and R. McGovern-Wilson. Maori settlement on Lee Island. In A.J. Anderson and R. McGovern-Wilson (eds), Beech Forest Hunters: the archaeology of Maori rockshelter sites on Lee Island, Lake Te Anau, in southern New Zealand, pp. 76-88. New Zealand Archaeological Association Monograph 18.

1991a Anderson, A.J., D. Foster and R. Wallace. Woodchips and wooden artefacts. In A.J. Anderson and R. McGovern-Wilson (eds), Beech Forest Hunters: the archaeology of Maori rockshelter sites on Lee Island, Lake Te Anau, in southern New Zealand, pp. 29-42. New Zealand Archaeological Association Monograph 18. 
1991b Anderson, A.J., J. Goulding and M. White. Bark and fibre artefacts. In A.J. Anderson and R. McGovern-Wilson (eds), Beech Forest Hunters: the archaeology of Maori rockshelter sites on Lee Island, Lake Te Anau, in southern New Zealand, pp. 43-55. New Zealand Archaeological Association Monograph 18.

1991c Anderson, A.J., R. McGovern-Wilson and S. Holdaway. Identification and analysis of faunal remains. In A.J. Anderson and R. McGovern-Wilson (eds), Beech Forest Hunters: the archaeology of Maori rockshelter sites on Lee Island, Lake Te Anau, in southern New Zealand, pp. 56-66. New Zealand Archaeological Association Monograph 18.

1991 Morrison, K. and A.J. Anderson. Lee Island and its environment. In A.J. Anderson and R. McGovern-Wilson (eds), Beech Forest Hunters: the archaeology of Maori rockshelter sites on Lee Island, Lake Te Anau, in southern New Zealand, pp. 3-8. New Zealand Archaeological Association Monograph 18.

1992 Anderson, A.J. and I.W.G. Smith. The Papatowai Site: new evidence and interpretations. Journal of the Polynesian Society 101:129-158.

1993 Anderson, A.J. Thomas Rangiwahia Ellison 1867-1904. The Dictionary of New Zealand Biography, Volume 2 (1870-1900), pp. 131-132. Department of Internal Affairs, Wellington.

1993 Anderson, A.J. and R.T. Wallace. Radiocarbon chronology of the Houhora site, Northland, New Zealand. New Zealand Journal of Archaeology 15:5-16.

1993 Spriggs, M. and A.J. Anderson. Late colonization of East Polynesia. Antiquity 67:200-217.

1994 Anderson, A.J. (ed), J.H. Beattie Traditional Lifeways of the Southern Maori: The Otago University Museum Ethnological Project, 1920. Otago University Press, Dunedin.

$1994 \mathrm{a}$ Anderson, A.J. Introduction: James Herries Beattie and the 1920 Project. In A. Anderson (ed), J.H. Beattie Traditional Lifeways of the Southern Maori: The Otago University Museum Ethnological Project, 1920, pp. 9-32. Otago University Press, Dunedin.

$1994 \mathrm{~b}$ Anderson, A.J. Comment on J. Peter White's paper. Site 820 and the evidence for early human occupation of Australia . Quaternary Australasia 12:30-31.

1994c Anderson, A.J. Moahunting in New Zealand. In G. Burenhult (ed), The Illustrated History of Humankind, Volume 4: New World and Pacific Civilizations, p. 163. Harper Collins, New York.

$1994 \mathrm{~d}$ Anderson, A.J. The occupation of the Pacific Islands, 50,000 BC-AD 1500: voyagers and fisherfolk. In G. Burenhult (ed), The Illustrated History of Humankind, Volume 4: New World and Pacific Civilizations, pp. 143-162. Harper Collins, New York.

$1994 \mathrm{e}$ Anderson, A.J. Palaeoenvironmental evidence of island colonization: a response. Antiquity 68:845-847.

$1994 \mathrm{f}$ Anderson, A.J. Thomas Rangiwahia Ellison 1866-68?-1904: Ngai Tahu and Te Atiawa; rugby player and lawyer. In C. Orange (ed), The Turbulent Years 1870-1900, pp. 18-20. Bridget Williams Books, Wellington. 
1994 Anderson, A.J. and T.F.G. Higham. Radiocarbon dating of oyster shell midden from beside the Dart Bridge site in western Otago. Archaeology in New Zealand 37:182-184.

1994 Anderson, A.J., H. Leach, I.W.G. Smith and R. Walter. Reconsideration of the Marquesan sequence in East Polynesian prehistory, with particular reference to Hane (MUH1). Archaeology in Oceania 29:29-54.

1994 McGlone, M.S., A.J. Anderson and R. Holdaway. An ecological approach to the early settlement of New Zealand. In D.G. Sutton (ed), The Origins of the First New Zealanders, pp. 136-163. Auckland University Press.

1995a Anderson, A.J. Current approaches in East Polynesian colonization research. Journal of the Polynesian Society 104:110-132.

1995b Anderson, A.J. Historical and archaeological aspects of muttonbirding in New Zealand. New Zealand Journal of Archaeology 17:35-55.

1995c Anderson, A.J. Kuri, Maori Dog. In C.M. King (ed), The Handbook of New Zealand Mammals, pp. 281-287. Oxford University Press, Auckland. Second edition.

1995 Jones, K.L., R. Hooker and A.J. Anderson. Bruce Bay Revisited: Archaic Maori Occupation and Haast's 'Palaeolithic'. New Zealand Journal of Archaeology 17:111-124.

1995 Walter, R. and A.J. Anderson. Archaeology of Niue Island: initial results. Journal of the Polynesian Society 104:471-481.

1996a Anderson, A.J. Adaptive voyaging and subsistence strategies in the early settlement of East Polynesia. In T. Akazawa and E. Szathmary (eds), Prehistoric Dispersal of Mongoloids, pp. 359-374. Oxford University Press.

1996b Anderson, A.J. An Early Maori village at Waihemo. Te Karaka 4.

1996c Anderson, A.J. Discovery of a prehistoric habitation site on Norfolk Island. Journal of the Polynesian Society 105:479-486.

1996d Anderson, A.J. Origins of Procellariidae hunting in the Southwest Pacific. International Journal of Osteoarchaeology 6:1-8.

1996e Anderson, A.J. Rat colonisation and Polynesian voyaging: another hypothesis. Rapa Nui Journal 10:31-35.

$1996 f$ Anderson, A.J. Te Whenua hou: prehistoric Polynesian colonisation of New Zealand and its impact on the environment. In T. Hunt and P. Kirch (eds), Historical Ecology in the Pacific Islands, pp. 271-283. Yale University Press.

$1996 \mathrm{~g}$ Anderson, A.J. Wakawaka and mahinga kai: models of traditional land management in southern New Zealand. In J. Davidson, G. Irwin, F. Leach, A. Pawley and D. Brown (eds), Oceanic Culture History: essays in honour of Roger Green, pp. 631-640. New Zealand Journal of Archaeology Special Publication.

1996h Anderson, A.J. Was Rattus exulans in New Zealand 2000 years ago? AMS radiocarbon ages from Shag River Mouth. Archaeology in Oceania 31:178-184. 
1996 Anderson, A.J. and B. Allingham. The high dune and swamp excavations. In A. Anderson, B. Allingham and I. Smith (eds), Shag River Mouth: the archaeology of an early southern Maori village, pp. 39-50. Research Papers in Archaeology and Natural History 27. ANH Publications, Australian National University, Canberra.

1996 Anderson, A.J. and W. Gumbley. Fishing gear. In A. Anderson, B. Allingham and I. Smith (eds), Shag River Mouth: the archaeology of an early southern Maori village, pp. 148-160. Research Papers in Archaeology and Natural History 27. ANH Publications, Australian National University, Canberra.

1996a Anderson, A.J. and I. Smith. Introduction and history of investigations. In A. Anderson, B. Allingham and I. Smith (eds), Shag River Mouth: the archaeology of an early southern Maori village, pp. 1-13. Research Papers in Archaeology and Natural History 27. ANH Publications, Australian National University, Canberra.

1996b Anderson, A.J. and I. Smith. Fish remains. In A. Anderson, B. Allingham and I. Smith (eds), Shag River Mouth: the archaeology of an early southern Maori village, pp. 237-244. Research Papers in Archaeology and Natural History 27. ANH Publications, Australian National University, Canberra.

1996c Anderson, A.J. and I. Smith. Shag River Mouth as an early Maori village. In A. Anderson, B. Allingham and I. Smith (eds), Shag River Mouth: the archaeology of an early southern Maori village, pp. 276-291. Research Papers in Archaeology and Natural History 27. ANH Publications, Australian National University, Canberra.

1996d Anderson, A.J. and I. Smith. The transient village in southern New Zealand. World Archaeology 27:359-371.

1996 Anderson, A.J., B. Allingham and I. Smith (eds), Shag River Mouth: the archaeology of an early southern Maori village. Research Papers in Archaeology and Natural History 27. ANH Publications, Australian National University, Canberra.

1996a Anderson, A.J., I. Smith and T. Higham. Radiocarbon chronology. In A. Anderson, B. Allingham and I. Smith (eds), Shag River Mouth: the archaeology of an early southern Maori village, pp. 60-69. Research Papers in Archaeology and Natural History 27. ANH Publications, Australian National University, Canberra.

1996b Anderson, A.J., T. Worthy and R. McGovern-Wilson. Moa remains and taphonomy. In A. Anderson, B. Allingham and I. Smith (eds), Shag River Mouth: the archaeology of an early southern Maori village, pp. 200-213. Research Papers in Archaeology and Natural History 27. ANH Publications, Australian National University, Canberra.

1996c Anderson, A.J., J. Head, R. Sim and D. West. Radiocarbon dates on shearwater bones from Beeton shelter, Badger Island, Bass Strait. Australian Archaeology 42:17-19.

1996 Allingham, B. and A.J. Anderson. Preliminary excavations. In A. Anderson, B. Allingham and I. Smith (eds), Shag River Mouth: the archaeology of an early southern Maori village, pp. 35-38. Research Papers in Archaeology and Natural History, 27. ANH Publications, Australian National University, Canberra.

1996 Boyd, B., M. McGlone, A.J. Anderson and R. Wallace. Late Holocene vegetation history at Shag River Mouth. In A. Anderson, B. Allingham and I. Smith (eds), Shag 
River Mouth: the archaeology of an early southern Maori village, pp. 257-275. Research Papers in Archaeology and Natural History 27. ANH Publications, Australian National University, Canberra.

1996 Leach, B.F., J.M. Davidson, L.M. Horwood and A.J. Anderson. The estimation of live fish size from archaeological cranial bones of the New Zealand barracouta Thyrsites atun. Tuhinga: Records of the Museum of New Zealand Te Papa Tongarewa $6: 1-25$.

1996 Smith, I. and A.J. Anderson. Collection, identification and quantification strategies. In A. Anderson, B. Allingham and I. Smith (eds), Shag River Mouth: the archaeology of an early southern Maori village, pp. 70-73. Research Papers in Archaeology and Natural History 27. ANH Publications, Australian National University Canberra.

1997a Anderson, A.J. Uniformity and regional variation in marine fish catches from prehistoric New Zealand. Asian Perspectives 36:1-26.

1997b Anderson, A.J. Seasonality and subsistence: Hunting and gathering in Murihiku. In M. McKinnon (ed), New Zealand Historical Atlas, plate 16. David Bateman in association with Department of Internal Affairs.

1997c Anderson, A.J. The dating of Rattus exulans bones - further discussion. Journal of the Polynesian Society 106:312-313.

1997 Anderson, A.J. and M. McGlone. A forceful impact: The East Polynesians' effect on fauna and flora. In M. McKinnon (ed), New Zealand Historical Atlas, plate 12. David Bateman in association with Department of Internal Affairs.

1997 Anderson, A.J., W. Ambrose, F. Leach and M. Weisler. Material sources of basalt and obsidian artefacts from a prehistoric settlement site on Norfolk Island, South Pacific. Archaeology in Oceania 32:39-46.

1998a Anderson, A.J. The Welcome of Strangers: an ethnohistory of southern Maori AD 1650-1850. University of Otago Press, Dunedin.

1998b Anderson, A.J. James Herries Beattie 1881-1972. In C. Orange (ed), Dictionary of New Zealand Biography, Volume Four 1921-1940, pp. 42-43. Auckland University Press and Department of Internal Affairs, Wellington.

1998c Anderson, A.J. Rating the Dating? New Zealand Science Monthly 9:2.

1998d Anderson, A.J. Reply to comments on "A production trend in AMS ages on Rattus exulans bone". Archaeology in New Zealand 41:231-234.

1998 Dickinson, W.R., D.V. Burley, P.D. Nunn, A.J. Anderson, G. Hope, A. De Biran, C. Burke and S. Matararaba. Geomorphic and archaeological landscapes of the Sigatoka Dune Site, Viti Levu, Fiji: Interdisciplinary investigations. Asian Perspectives 37:1-31.

1998 Holdaway, R.N. and A.J. Anderson. ${ }^{14} \mathrm{C}$ AMS dates on Rattus exulans bones from natural and archaeological contexts on Norfolk Island, South-west Pacific. Archaeology in New Zealand 41:195-198.

1998 Smith, I.W.G. and A.J. Anderson. Radiocarbon dates from archaeological rat bones: the Pleasant River case. Archaeology in Oceania 33:88-91. 
1998 Worthy, T.H., R. Walter and A.J. Anderson. Fossil and archaeological avifauna of Niue Island, Pacific Ocean. Notornis 45:177-190.

1999 Anderson, A.J. Moas and moa-hunting. In T. Akimichi (ed), Ethnobiology of the Austronesians, pp. 325-338. Heibonsha, Tokyo.

1999 Anderson, A.J. and G. Clark. The Age of Lapita Settlement in Fiji. Archaeology in Oceania 34:31-39.

1999 Higham, T.F.G., A.J. Anderson and C. Jacomb. Dating the First New Zealanders: the chronology of Wairau Bar. Antiquity 73:420-427.

1999 White, J.P. and A.J. Anderson. Prehistory of Norfolk Island. Nature Australia Spring 1999:26-29.

1999 Worthy, T.H., A.J. Anderson and R.E. Molnar. Megafaunal expression in a land without mammals - the first fossil faunas from terrestrial deposits in Fiji (Vertebrata: Amphibia, Reptilia, Aves). Senckenbergiana biologica 79:237-242.

2000a Anderson, A.J. Defining the period of moa extinction. Archaeology in New Zealand 43:195-200.

2000b Anderson, A.J. Differential reliability of ${ }^{14} \mathrm{C}$ AMS ages of Rattus exulans bone gelatin in south Pacific prehistory. Journal of the Royal Society of New Zealand 30:243-261.

2000c Anderson, A.J. Implications of prehistoric obsidian transfer in South Polynesia. Bulletin of the Indo-Pacific Prehistory Association 20:117-123.

2000d Anderson, A.J. Slow boats from China: issues in the prehistory of Indo-Pacific seafaring. In S. O'Connor and P. Veth (eds), East of Wallace's Line: studies of past and present maritime cultures of the Indo-Pacific region, pp. 13-50. Balkema, Rotterdam.

2000e Anderson, A.J. The advent chronology of south Polynesia. In P. Wallin and H. Martinsson-Wallin (eds), Essays in honour of Arne Skjolsvold 75 years, pp. 73-82. Occasional Papers of the Kon-Tiki Museum 5.

$2000 \mathrm{f}$ Anderson, A.J. Skinner, H. Devenish 1886-1978. In C. Orange (ed), Dictionary of New Zealand Biography, Volume Four 1921-1940, pp. 479-480. Auckland University Press and Department of Internal Affairs, Wellington.

2000 Anderson, A.J. and T. Murray (eds), Australian Archaeologist: Collected papers in honour of Jim Allen. Coombs Academic Publishing, Australian National University, Canberra.

2000 Anderson, A.J. and T. Murray. J. Allen: Australian archaeologist. In A.J. Anderson and T. Murray (eds), Australian Archaeologist: Collected papers in honour of Jim Allen, pp. 8-20. Coombs Academic Publishing, Australian National University, Canberra.

2000 Anderson, A.J. and G. O'Regan. To the final shore: prehistoric colonisation of the Subantarctic islands in South Polynesia. In A.J. Anderson and T. Murray (eds), Australian Archaeologist: Collected papers in honour of Jim Allen, pp. 440-454. Coombs Academic Publishing, Australian National University, Canberra.

2000a Anderson, A.J., G.R. Clark and T.H. Worthy. An inland Lapita site in Fiji. Journal of the Polynesian Society 109:311-316. 
2000b Anderson, A.J., E. Conte, G. Clark, Y. Sinoto and F. Petchey. Renewed excavations at Motu Paeao, Maupiti Island, French Polynesia: preliminary results. New Zealand Journal of Archaeology 21(1999):47-65.

2000c Anderson, A.J., P. Wallin, H. Martinsson-Wallin and G. Hope. Towards a first prehistory of Kiritimati (Christmas) Island, Republic of Kiribati. Journal of the Polynesian Society 109:273-294.

2000 Leach, B.F., J.M. Davidson, K. Fraser and A.J. Anderson. Pre-European catches of barracouta, Thyrsites atun, at Long Beach and Shag River Mouth, Otago, New Zealand. Archaeofauna 8:11-30.

2000 Steadman, D.W., T.H. Worthy, A.J. Anderson and R. Walter. New species and records of birds from prehistoric sites on Niue, Southwest Pacific. Wilson Bulletin 112:165-186.

2001a Anderson, A.J. Mobility models of Lapita migration. In G.R. Clark, A.J. Anderson and T. Vunidilo (eds), The Archaeology of Lapita Dispersal in Oceania: papers from the Fourth Lapita Conference, June 2000, Canberra, Australia, pp. 15-23. Terra Australis 17.

2001b Anderson, A.J. No meat on that beautiful shore: the prehistoric abandonment of subtropical Polynesian islands. In A.J. Anderson and B.F. Leach (eds), Zooarchaeology of Oceanic Coasts and Islands: Papers from the 8th International Congress of the International Council of Archaeozoology, 23-29 August 1998, Victoria B.C., Canada, pp. 14-23. Special Issue of the International Journal of Osteoarchaeology 11.

2001c Anderson, A.J. The chronology of prehistoric colonization in French Polynesia. In C.M. Stevenson, G. Lee and F.J. Morin (eds), Pacific 2000: Proceedings of the Fifth International conference on Easter Island and the Pacific, pp. 247-252. Easter Island Foundation, Los Osos.

2001d Anderson, A.J. Towards the sharp end: the form and performance of prehistoric Polynesian voyaging canoes. In C.M. Stevenson, G. Lee and F.J. Morin (eds), Pacific 2000: Proceedings of the Fifth International conference on Easter Island and the Pacific, pp. 29-36. Easter Island Foundation, Los Osos.

2001e Anderson, A.J. The origins of muttonbirding in New Zealand. New Zealand Journal of Archaeology 22(2000):5-14.

2001 Anderson, A.J. and G.R. Clark. Advances in New Zealand mammalogy 1990-2000: Polynesian dog or kuri. Journal of the Royal Society of New Zealand 31:161-163.

2001 Anderson, A.J. and R.C. Green. Domestic and religious structures in the Emily Bay settlement site, Norfolk Island. In A.J. Anderson and J.P. White (eds), The Prehistoric Archaeology of Norfolk Island, Southwest Pacific, pp. 43-52. Supplement 27, Records of the Australian Museum.

2001 Anderson, A.J. and B.F. Leach (eds), Zooarchaeology of Oceanic Coasts and Islands: Papers from the 8th International Congress of the International Council of Archaeozoology, 23-29 August 1998, Victoria B.C., Canada. Special Issue of the International Journal of Osteoarchaeology 11. 
2001 Anderson, A.J. and B.F. Leach. Introduction. In A.J. Anderson and B.F. Leach (eds), Zooarchaeology of Oceanic Coasts and Islands: Papers from the 8th International Congress of the International Council of Archaeozoology, 23-29 August 1998, Victoria B.C., Canada, pp. 2-3. Special Issue of the International Journal of Osteoarchaeology 11.

2001 Anderson, A.J. and J.P. White (eds), The Prehistoric Archaeology of Norfolk Island, Southwest Pacific. Supplement 27, Records of the Australian Museum.

2001a Anderson. A.J. and J.P. White. Approaching the prehistory of Norfolk Island. In A.J. Anderson and J.P. White (eds), The Prehistoric Archaeology of Norfolk Island, Southwest Pacific, pp. 1-9. Supplement 27, Records of the Australian Museum.

2001b Anderson, A.J. and J.P. White. Prehistoric settlement on Norfolk Island and its Oceanic context. In A.J. Anderson and P.J. White (eds), The Prehistoric Archaeology of Norfolk Island, Southwest Pacific, pp. 135-141. Supplement 27, Records of the Australian Museum.

2001 Anderson, A.J., I. Lilley and S. O'Connor (eds), Histories of Old Ages: essays in honour of Rhys Jones. Pandanus Books, Australian National University, Canberra.

2001a Anderson, A.J., L. Ayliffe, D. Questiaux, T. Sorovi-Vunidilo, N. Spooner, and T. Worthy. The terminal age of the Fijian megafauna. In A.J. Anderson, I. Lilley and S. O'Connor (eds), Histories of Old Ages: essays in honour of Rhys Jones, pp. 251-264. Pandanus Books, Australian National University, Canberra.

2001b Anderson, A.J., S. Bedford, G.R. Clark, I. Lilley, C. Sand, G. Summerhayes and R. Torrence. An inventory of Lapita sites containing dentate-stamped pottery. In G.R. Clark, A.J. Anderson and T. Vunidilo (eds), The Archaeology of Lapita Dispersal in Oceania: papers from the Fourth Lapita Conference, June 2000, Canberra, Australia, pp. 1-13. Terra Australis 17.

2001c Anderson, A.J., T.F.G. Higham, and R. Wallace. The radiocarbon chronology of the Norfolk Island archaeological sites. In A.J. Anderson and J.P. White (eds), The Prehistoric Archaeology of Norfolk Island, Southwest Pacific, pp. 33-42. Supplement 27, Records of the Australian Museum.

2001d Anderson, A.J., I.W.G. Smith and J.P White. Archaeological fieldwork on Norfolk Island. In A.J. Anderson and J.P. White (eds), The Prehistoric Archaeology of Norfolk Island, Southwest Pacific, pp. 11-32. Supplement 27, Records of the Australian Museum.

2001 Clark, G.R. and A.J. Anderson. The age of the Yanuca Lapita site, Viti Levu, Fiji. New Zealand Journal of Archaeology 22(2000):15-30.

2001 Clark, G.R., A.J. Anderson and T. Vunidilo (eds), The Archaeology of Lapita Dispersal in Oceania: papers from the Fourth Lapita Conference, June 2000, Canberra, Australia. Terra Australis 17.

2001 Clark, G.R., A.J. Anderson and S. Matararaba. The Lapita site at Votua, northern Lau Islands, Fiji. Archaeology in Oceania 36:134-143.

2001 Holdaway, R.N. and A.J. Anderson. Avifauna from the Emily Bay settlement site, Norfolk Island: a preliminary account. In A.J. Anderson and J.P. White (eds), The Prehistoric Archaeology of Norfolk Island, Southwest Pacific, pp. 85-100. Supplement 27, Records of the Australian Museum. 
2001 MacPhail, M.K., G.S. Hope and A.J. Anderson. Polynesian plant introductions in the southwest Pacific: initial pollen evidence from Norfolk Island. In A.J. Anderson and J.P. White (eds), The Prehistoric Archaeology of Norfolk Island, Southwest Pacific, pp. 123-134. Supplement 27, Records of the Australian Museum, Sydney.

2001 Matisoo-Smith, E., K.A. Horsburgh, J.H. Robins and A.J. Anderson. Genetic variation in archaeological Rattus exulans remains from the Emily Bay settlement site, Norfolk Island. In A.J. Anderson and J.P. White (eds), The Prehistoric Archaeology of Norfolk Island, Southwest Pacific, pp. 81-84. Supplement 27, Records of the Australian Museum.

2001 Schmidt, L., A.J. Anderson and R. Fullagar. Shell and bone artefacts from the Emily Bay settlement site, Norfolk Island. In A.J. Anderson and J.P. White (eds), The Prehistoric Archaeology of Norfolk Island, Southwest Pacific, pp. 67-74. Supplement 27, Records of the Australian Museum.

2001 Turner, M., A.J. Anderson and R. Fullagar. Stone artefacts from the Emily Bay settlement site, Norfolk Island. In A.J. Anderson and P.J. White (eds), The Prehistoric Archaeology of Norfolk Island, Southwest Pacific, Supplement 27, Records of the Australian Museum.

2001 Walter, R. and A.J. Anderson. Fishbone from the Emily Bay settlement site, Norfolk Island. In A.J. Anderson and J.P. White (eds), The Prehistoric Archaeology of Norfolk Island, Southwest Pacific, pp. 101-108. Supplement 27, Records of the Australian Museum.

2002a Anderson, A.J. A fragile plenty: pre-European Maori and the New Zealand environment. In E. Pawson and T. Brooking (eds), Environmental Histories of New Zealand, pp. 19-34. Oxford University Press, Melbourne.

2002b Anderson, A.J. Faunal collapse, landscape change and settlement history in Remote Oceania. World Archaeology 33:375-390.

2002c Anderson, A.J. Rat bone, recollection and record. Archaeology in New Zealand 45:216-219.

2002 Anderson, A.J. and Y.H. Sinoto. New radiocarbon ages of colonization sites in East Polynesia. Asian Perspectives 41:242-257.

2002 Anderson, A.J. and R.K. Walter. Landscape and culture change on Niue Island, West Polynesia. In T. Ladefoged, T. and M. Graves (eds), Pacific Landscapes: archaeological approaches, pp. 153-172. Easter Island Foundation, Los Osos.

2002a Anderson, A.J., S. Haberle, G. Rojas, A. Seelenfreund, I.W.G. Smith and T. Worthy. An archaeological exploration of Robinson Crusoe Island, Juan Fernandez Archipelago, Chile. In S. Bedford, C. Sand and D. Burley (eds), Fifty Years in the Field: essays in honour and celebration of Richard Shutler Jr's archaeological career, pp. 239-249. New Zealand Archaeological Association Monograph 25.

2002b Anderson, A.J., H. Martinsson-Wallin and P. Wallin. The Prehistory of Kiritimati (Christmas) Island, Republic of Kiribati: Excavations and Analyses. Occasional Papers of The Kon-Tiki Museum 6.

2002 Sheppard, P.J., A.J. Anderson and R.K. Walter. Geochemical analysis and sourcing 
of archaeological stone from Niue. In R. Walter and A.J. Anderson The Archaeology of Niue Island, West Polynesia. Bishop Museum Bulletin in Anthropology 10.

2002 Walter, R. and A.J. Anderson. The Archaeology of Niue Island, West Polynesia. Bishop Museum Bulletin in Anthropology 10.

2002 Worthy, T., A.J. Anderson and R.K. Walter. Fossil fauna from Niue island. In R. Walter and A.J. Anderson The Archaeology of Niue Island, West Polynesia. Bishop Museum Bulletin in Anthropology 10.

2003a Anderson, A.J. Investigating early settlement on Lord Howe Island. Australian Archaeology 57:98-102.

2003b Anderson, A.J. Uncharted waters: colonization of remote Oceania. In M. Rockman and J. Steele (eds), Colonization of Unfamiliar Landscape, pp. 169-189. Routledge, London.

2003a Anderson, A.J., E. Conte, P.V. Kirch and M. Weisler. Cultural chronology in Mangareva (Gambier Islands), French Polynesia: evidence from recent radiocarbon dating. Journal of the Polynesian Society 112:119-140.

2003b Anderson, A.J., E. Conte, P.V. Kirch and M. Weisler. Recherches archéologiques aux îles Gambier (2001). In H. Marchesi (ed), Bilan de la recherche archéologique en Polynésie Française. Dossier d'Archéologie Polynésienne 2, pp. 137-146. Service de la Culture et du Patrimoine, Punaauia.

2003 Bellwood, P., J. Stevenson, A. Anderson and E. Dizon. Archaeological and palaeoenvironmental research in Batanes and Ilocos Norte provinces, northern Philippines. Bulletin of the Indo-Pacific Prehistory Association 23:141-162.

2003 Conte, E. and A.J. Anderson. Radiocarbon ages for two sites on Ua Huka, Marquesas. Asian Perspectives 42:155-160.

2003 Kennett, D.J., A.J. Anderson, M. Prebble and E. Conte. La colonization et les fortifications de Rapa. In H. Marchesi (ed), Bilan de la recherche archéologique en Polynésie Française. Dossier d'Archéologie Polynésienne 2, pp. 165-170. Service de la Culture et du Patrimoine, Punaauia.

2003 Szabo, K., H. Ramirez, A. Anderson and P. Bellwood. Prehistoric subsistence strategies on the Batanes Islands, Northern Philippines. Bulletin of the Indo-Pacific Prehistory Association 23:163-172.

2004a Anderson, A.J. Fear and loathing on desert islands. In M. Campbell (ed), Digging into History: 50 years of the New Zealand Archaeological Association, pp. 55-57. Archaeology in New Zealand Special Issue.

$2004 \mathrm{~b}$ Anderson, A.J. Initial human dispersal in Remote Oceania: pattern and explanation. In C. Sand (ed), Pacific Archaeology: assessments and prospects. Proceedings of the International Conference for the 50th anniversary of the first Lapita excavation, KonéNouméa 2002, pp. 71-84. Le cahiers d'Archéologie en Nouvelle-Calédonie 15.

2004c Anderson, A.J. Islands of ambivalence. In S. Fitzpatrick (ed), Voyages of Discovery: The archaeology of islands, pp. 251-274. Praeger, London.

2004d Anderson, A.J. It's about time: the Indo-pacific colonization project. In T. Murray (ed), Archaeology from Australia, pp. 3-17. La Trobe University, Melbourne. 
2004e Anderson, A.J. Maori. Enciclopedia Archeologica, pp. 941-942. Instituto della Enciclopedia Italiana, Roma.

$2004 f$ Anderson, A.J. Shag River Mouth. Enciclopedia Archeologica, p.977. Instituto della Enciclopedia Italiana, Roma.

2004g Anderson, A.J. Wairau Bar. Enciclopedia Archeologica, pp. 989-990. Instituto della Enciclopedia Italiana, Roma.

2004h Anderson, A.J. The age disconformity in AMS radiocarbon results on Rattus exulans bone. New Zealand Journal of Archaeology 24(2002):149-156.

2004 Anderson, A.J. and T. Higham. The age of rat introduction in New Zealand: further evidence from Earthquakes \#1, North Otago. New Zealand Journal of Archaeology 24(2002):135-147.

2004 Anderson, A.J., E. Conte, P.V. Kirch and M. Weisler. Archaeological investigations in the Gambier Islands, French Polynesia. In C. Sand (ed), Pacific Archaeology: assessments and prospects. Proceedings of the International Conference for the 50th anniversary of the first Lapita excavation, Koné-Nouméa 2002, pp. 343-352. Le cahiers d'Archéologie en Nouvelle-Calédonie 15.

2004 Burley, D., D. Steadman and A.J. Anderson. The volcanic outlier of 'Ata in Tongan prehistory: reconsideration of its role and settlement chronology. New Zealand Journal of Archaeology 25 (2003):89-106.

2004 Conte, E., P.V. Kirch, M.I. Weisler and A.J. Anderson. Archaeological field investigations. In E. Conte and P.V. Kirch (eds), Archaeological investigations in the Mangareva Islands (Gambier Archipelago), French Polynesia, pp. 33-93. Archaeological Research Facility Contribution 62, University of California at Berkeley.

2004 Higham, T.F.G., R.E.M. Hedges, A.J. Anderson, C. Bronk Ramsey and B. Fankhauser. New AMS radiocarbon determinations of Rattus exulans bone from Shag River Mouth, New Zealand. Radiocarbon 46:207-218.

2004 Kennett, D.J., A.J. Anderson, M.J. Cruz, G.R. Clark and G. Summerhayes. Geochemical characterization of Lapita pottery via inductively-coupled plasma-mass spectrometry. Archaeometry 46:35-46.

2004 Kirch, P.V., J. Coil, M.I. Weisler, E. Conte, and A.J. Anderson. Radiocarbon dating and site chronology. In E. Conte and P.V. Kirch (eds), Archaeological investigations in the Mangareva Islands (Gambier Archipelago), French Polynesia, pp. 94-105. Archaeological Research Facility Contribution 62, University of California at Berkeley.

2004 Phear, S., G. Clark and A.J. Anderson. A radiocarbon chronology for Palau. In C. Sand (ed), Pacific Archaeology: assessments and prospects. Proceedings of the International Conference for the 50th anniversary of the first Lapita excavation, Koné-Nouméa 2002, pp. 255-263. Le cahiers d'Archéologie en Nouvelle-Calédonie 15.

2005a Anderson, A.J. Crossing the Strait: archaeological chronology in the Batanes Islands, Philippines and the regional sequence of Neolithic dispersal. Journal of Austronesian Studies 1:27-48. 
2005b Anderson, A.J. Keynote address: Distance looks our way. Remoteness and isolation in early East and South Polynesia. In C.M. Stevenson, J.M. Ramirez, E.J. Morin and N. Barbacci (eds), The Renaca papers: VI International Conference on Rapa Nui and the Pacific, pp. 1-12. Easter Island Foundation, Los Osos.

2005c Anderson, A.J. Settlement of the Pacific. Berkshire Encyclopaedia of World History.

2005d Anderson, A.J. Subpolar settlement in South Polynesia. Antiquity 79:791-800.

2005a Anderson, A.J., J. Chappell, G. Clark and S. Phear. Comparative radiocarbon dating of lignite, pottery and charcoal samples from Babeldaob Island, Republic of Palau. Radiocarbon 47:1-9.

2005b Anderson, A.J., T. Higham and N. Ritchie. The chronology and interpretation of Italian Creek rockshelter, Central Otago. Archaeology in New Zealand 48:242-247.

2005c Higham, T.F.G., A.G. Anderson, C. Bronk Ramsey and C. Tompkins. Diet-derived variations in radiocarbon and stable isotopes: a case study from Shag River Mouth, New Zealand. Radiocarbon 47:367-375.

2006a Anderson, A.J. Alternative interpretations of structural evidence at Rakaia Mouth, New Zealand. Archaeology in Oceania 41:123-126.

$2006 \mathrm{~b}$ Anderson, A.J. Islands of Exile: ideological motivation in maritime migration. Journal of Island and Coastal Archaeology 1:33-47.

2006c Anderson, A.J. Polynesian seafaring and American horizons: a response to Jones and Klar. American Antiquity 71: 759-764.

2006d Anderson, A.J. Retrievable time: prehistoric colonization of South Polynesia from the outside in and the inside out. In T. Ballantyne and B. Moloughney (eds), Disputed Histories: imagining New Zealand's pasts, pp. 25-41. University of Otago Press, Dunedin.

2006 Anderson, A.J. and T.F.G. Higham. Response to Beavan Athfield's comment on "Diet-derived variations in radiocarbon and stable isotopes: a case study from Shag River Mouth, New Zealand”. Radiocarbon 48:1-2.

2006a Anderson, A.J., J. Chappell, M. Gagan, and R. Grove. Prehistoric maritime migration in the Pacific Islands: an hypothesis of ENSO forcing. The Holocene $16: 1-6$.

2006b Anderson, A.J., R. Roberts, W. Dickinson, G. Clark, D. Burley, A. De Biran, G. Hope and P. Nunn. Times of sand: sedimentary history and archaeology at the Sigatoka dunes, Fiji. Geoarchaeology 21:131-154.

2006 Clark, G., A.J. Anderson and D. Wright. Human colonization of the Palau Islands, Western Micronesia. Journal of Island and Coastal Archaeology 1:215-232.

2006a Kennett, D., A.J. Anderson and B. Winterhalder. The ideal free distribution, agricultural origins and the colonization of the Pacific. In D. Kennett and B. Winterhalder (eds), Behavioural Ecology and the Transition to Agriculture, pp. 265-288. University of California Press, Berkeley.

2006b Kennett, D., A.J. Anderson, M. Prebble, E. Conte and J. Southon. Prehistoric human impacts on Rapa, French Polynesia. Antiquity 80:1-15. 
2007a Anderson, A.J. Chapter 7: Island archaeology: with a case study of colonization and anthropogenic change in the Pacific Islands. In G. Baldaccino (ed), A World of Islands: an island studies reader, pp. 237-266. Agenda Academic, Luqa, Malta and Institute of Island Studies, Charlottetown, PEI, Canada.

2007b Anderson, A.J. Colonial illusion and reality at the Old World's end. In B. Hardh (ed), On the Road: Studies in honour of Lars Larsson. Almqvist and Wiksell International.

2007c Anderson, A.J. Discussion: Middens of the sea people. In N. Milner, O.E. Craig and G.N. Bailey (eds), Shell Middens in Atlantic Europe. Oxbow Press.

2007 Anderson, A.J., K. Green and F. Leach (eds), Vastly Ingenious: The archaeology of Pacific material culture in honour of Janet M. Davidson. Otago University Press, Dunedin.

2007 Anderson, A.J., H. Martinsson-Wallin and K. Stothert. Ecuadorian sailing rafts and Oceanic landfalls. In A.J. Anderson, K. Green and F. Leach (eds), Vastly Ingenious, The archaeology of Pacific material culture in honour of Janet M. Davidson. Otago University Press, pp. 117-133.

2007 Anderson, A.J. Short and sometimes sharp: human impacts on marine resources in the archaeology history of South Polynesia. In T.C. Rick and J.M. Erlandson (eds), Human Impacts on Ancient Marine Environments: a global perspective. University of California Press.

2007 Anderson, A.J. Maori Land and Livelihood, AD 1250-1850. In R. Scott (ed), The Natural History of Canterbury. Canterbury University Press.

2007 Anderson, A.J. Origins, settlement and society of South Polynesia. In G. Burns (ed), The New Oxford History of New Zealand. In press.

2007 Anderson. A.J., M. Gagan and J. Shulmeister. Mid-Holocene cultural dynamics and climatic change in the western Pacific. In D. Anderson, K. Maasch and D. Sandweiss (eds), Climatic Change and Cultural Dynamics: a global perspective on Holocene transitions. Academic Press.

2007 O'Connor, S. and A.J. Anderson (eds), Maritime migration and colonization in Indo-Pacific prehistory. Asian Perspectives 47(1).

2008 Tau, Te.M. and A.J. Anderson (eds), Ngai Tahu: A Migration History: The Carrington Text. Bridget Williams Books, Wellington.

n.d. Anderson, A.J. and D. Kennett (eds), The Prehistory of Rapa Island, French Polynesia. New Zealand Archaeological Association Monograph. In prep.

n.d. Clark, G. and A.J. Anderson (eds), The Early Prehistory of Fiji. Terra Australis, Australian National University. In prep. 